\title{
Effects of Chicken Farming on Soil Phosphorus Availability and Associated Microbial Properties in Lei Bamboo (Phyllostachys praecox) Forest Ecosystems
}

\section{Xu Gai}

China National Bamboo Research Center

Shaocui Li

Chinese Academy of Forestry

Xiaoping Zhang

China National Bamboo Research Center

\section{Fangyuan Bian}

China National Bamboo Research Center

\section{Chuanbao Yang}

China National Bamboo Research Center

Zheke Zhong ( $\square$ zhekez@163.com )

China National Bamboo Research Center

\section{Research}

Keywords: Bamboo-chicken farming, phosphorus fractions, phosphobacteria, grazing density, sustainable land use, Lei bamboo

Posted Date: January 19th, 2021

DOl: https://doi.org/10.21203/rs.3.rs-148399/v1

License: (c) (i) This work is licensed under a Creative Commons Attribution 4.0 International License. Read Full License 


\section{Abstract}

Background: Bamboo-chicken farming (BCF) is a popular bamboo complex management model in Southeast Asia owing to its high economic benefits. However, the effects of BCF on phosphorus (P) availability and the associated microbial communities in soil remain poorly understood. In this study, we compared the soil properties, $\mathrm{P}$ fractions, phosphatase activities, and bacterial community compositions in the surface soil $(0-20 \mathrm{~cm}$ ) of a typical bamboo (Phyllostachys praecox)-chicken farming system under different grazing densities (represented as distances of 5, 15, 25, and $35 \mathrm{~m}$ from the henhouse, respectively). The variables were also compared with the soil measurements from an adjacent pure bamboo forest without chicken framing (control site).

Results: We observed a significant increase in soil pH, cation exchange capacity (CEC), total $N(T N)$, total $\mathrm{P}(\mathrm{TP})$, and available potassium (AK) with increasing grazing density, while soil organic carbon (SOC) showed no significant difference between the sites. The total $\mathrm{P}$ accumulation of the soil was also more rapid than that of SOC and TN with increasing grazing density. Labile $\mathrm{P}$ and moderately labile $\mathrm{P}$ dominated the soil $\mathrm{P}$ accumulation under BCF. In particular, Resin-Pi (labile P), $\mathrm{NaHCO}_{3}-\mathrm{Pi}$ (labile P), and 1 M HCl-Pi (moderately labile P) increased by $100-233 \%, 83-183 \%$ and $414-1314 \%$, respectively, compared with the control values. In contrast, the contribution of labile or moderately labile organic phosphorus to the total phosphorus $(\mathrm{Pt})$ content decreased significantly with increasing grazing density from $38.54 \%$ (control) to $17.65 \%$ (5-m site). Phosphatase activity also increased with increasing grazing density, which suggests that BCF effectively promoted the mineralization of soil Po. A redundancy analysis showed that the changes in bacterial community structure were closely related to Resin-Pi and 1 $\mathrm{M} \mathrm{HCl}-\mathrm{Pi}\left(\mathrm{r}^{2}=0.938\right.$ and 0.958 , respectively). The relative abundances of the phosphobacteria Flavobacterium, Pseudomonas, Streptomyces, and Arthobacter increased with increasing grazing density, while the abundance of Burkholderia decreased at the 5-m site. Inorganic P (Resin-Pi, $\mathrm{NaHCO}_{3}-\mathrm{Pi}$, and $1 \mathrm{M}$ $\mathrm{HCl}-\mathrm{Pi}$ ) was positively correlated with the abundances of Flavobacterium, Pseudomonas, and Arthrobacter but negatively correlated with the abundance of Burkholderia; this highlights the different functional bacteria involved in P cycling.

Conclusions: We conclude that BCF generally increases soil P availability and supply, and the changes in the $\mathrm{P}$ forms were closely related to the changes in soil bacterial community composition. However, excessive grazing density or long-term BCF practices can cause soil nutrient imbalance, labile and moderately labile $\mathrm{P}$ accumulation, and $\mathrm{P}$ leaching. Therefore, appropriate grazing densities and/or an interval of no grazing are required under the BCF model for effective and sustainable bamboo forest management.

\section{Background}

Bamboo is an important component of tropical and subtropical forest ecosystems and is also a widely exploited natural resource in southern China (Phimmachanh et al., 2015; FAO, 2010). The bamboo forest industry has a long history in China, and the planting of pure forests is still the main management 
method for bamboo farming (Cai et al., 2018). However, this has led to soil degradation, site productivity decline, and regional ecological and environmental deterioration (Luo et al., 1997). As a result, the bamboo forest industry has been gradually shifting toward an efficient compound management model to improve the utilization rate of bamboo forest resources and to balance economic benefits with ecological functions (Dev et al., 2017; Zhu, 2012). Because bamboo forests are usually harvested by selective harvesting methods and purely managed with a single-layer canopy (Song et al., 2011), it is advantageous to raise animals under bamboo canopies. Chicken farming in a bamboo forest was found to both increase the soil nutrient content (organic carbon, total nitrogen, total phosphorus, total potassium) and promote the growth of Moso bamboo (Phyllostachys edulis) (Zhu et al., 2018). However, the continuous input of chicken manure to the soil surface and the physical soil disturbance by grazing chickens increases the risks of soil surface erosion, manure leakage, biodiversity reduction, and soil degradation (Zhang et al., 2019; Cai et al., 2018). Bamboo forests and chicken farming can be mutually beneficial owing to their large ecological niche differences (Wu et al., 2013); however, the significant impact of chicken farming on soil quality must be addressed.

Phosphorus $(P)$ is a key restrictive nutrient element in forest ecosystems (Vitousek et al., 2010; Chen et al., 2018), and its bioavailability affects plant growth and microbial properties (Tan et al., 2013; Zhao et al., 2014). However, only a relatively small amount of soil $P$ can be absorbed and utilized by plants owing to its low mobilization (Schachtman et al., 1998). A deficiency in P inhibits photosynthesis, respiration, and other metabolic and biosynthetic processes in bamboo (Liu et al., 2015). P deficiency can also reduce enzyme activity related to carbon and nitrogen metabolism (Burman et al., 2009). Furthermore, insufficient $\mathrm{P}$ can cause abnormal root structures by altering the number and density of lateral roots, which affects the ecological stability of bamboo forests (Lin et al., 2014). Therefore, research on the impacts of bamboo-chicken farming (BCF) on soil $\mathrm{P}$ availability is necessary for ensuring the sustainable management of bamboo forests.

Different $\mathrm{P}$ fractions have different levels of bioavailability for plant and microbial uptake. For example, plants can directly absorb and utilize dissolved P in soil (Helfenstein et al., 2018). Inorganic phosphorus (Pi) associated with iron and aluminum minerals is a potential source of plant- and microbial-available $\mathrm{P}$ and is typically transformed within weeks or months (Helfenstein et al., 2018). In contrast, residual P is more stable and is considered unavailable for plant uptake (Vitousek et al., 2010). Therefore, changes in the fractions of soil $\mathrm{P}$ in bamboo-chicken farms (BCF) can largely determine the soil P availability, which in turn affects microbial community structure and bamboo forest production. Various factors control the dynamic changes in the content of $P$ fractions, including soil texture (Tokural et al., 2011), management systems (Liu et al., 2019), chemical and organic fertilizers (Liu et al., 2020; Gichangi et al., 2009), and biology (Beutler et al., 2015; Li, 2001). Previous studies have shown that overgrazing may hinder the mineralization of phosphorus (Ford et al., 2016) and reduce its solubility (Sigua et al., 2014). Moreover, Li (2001) reported that long-term grazing reduced the soil $P$ stock-particularly for organic $P$ (Po). In addition, $\mathrm{Li}$ (2001) found that soil Fe-P changes were more sensitive to grazing in grassland ecosystems and could therefore be used to indicate the effect of grazing on soil. These findings highlight the need to investigate the $\mathrm{P}$ fractions in soil under BCF to infer the effects of grazing on soil P stocks. 
Microorganisms are involved in several key biogeochemical processes of P cycling, including P uptake, release, and redistribution (Richardson \& Simpson, 2011; Pistocchia et al., 2018; Zhang et al., 2020). Therefore, studying the changes in microbial community structure under BCF conditions, especially Prelated microorganisms, can further our understanding of the dominant mechanisms underlying the changes in soil $\mathrm{P}$ fractions. Furthermore, changes in microbial communities can affect soil enzymes and their activities, as enzymes in soil are mainly secreted by microorganisms (Tarafdar \& Claassen, 1988; Waring et al., 2014). Acid phosphatase (ACP) and alkaline phosphatase (ALP) are non-specific enzymes that promote the bioavailability of phosphorus in soil by catalyzing the hydrolysis of ester-phosphate bonds of monoesters in orthophosphate (other than phytate) (Fraser et al., 2015; Nannipieri et al., 2010). Moreover, the ACP and ALP activities in soil have been measured to assess the conversion process of Po to $\mathrm{Pi}$, as they are considered to play a major role in this process (Tarafdar \& Jungk, 1987). Therefore, combining the study of the microbially mediated $\mathrm{Pi}$ supply pathway with $\mathrm{P}$ fraction change mechanisms can improve our understanding of $\mathrm{P}$ biogeochemical cycles and bioavailability under BCF conditions.

In this study, we aimed to determine the impact of chicken farming on soil P availability and microbial community structures in Lei bamboo (Phyllostachys praecox) forests. We assessed the biogeochemical changes under different grazing intensities to elucidate the relationships between the $\mathrm{P}$ fractions and bacterial community and to evaluate the sustainability of BCF systems. Specifically, we tested the following hypotheses: (1) chicken farming largely affects soil P status-especially the P fractions; (2) grazing density significantly affects the distribution of organic and inorganic $\mathrm{P}$ fractions; and (3) chicken farming significantly increases soil P availability and accelerates soil phosphatase activity, which consequently impacts the bacterial community structure in soil.

\section{Materials And Methods}

\subsection{Experimental site}

The study site is located in Jingshan Town (N 30²4', E 11952', $125 \mathrm{~m} \mathrm{ASL),} \mathrm{which} \mathrm{is} \mathrm{northwest} \mathrm{of}$ Hangzhou in Zhejiang Province, China (Figure 1). The region has a mid-latitude subtropical monsoon climate, with an average annual rainfall and temperature of approximately $1454 \mathrm{~mm}$ and $17.8{ }^{\circ} \mathrm{C}$, respectively. The minimum and maximum temperatures are $2{ }^{\circ} \mathrm{C}$ in January and $39{ }^{\circ} \mathrm{C}$ in July, respectively. The experiment site is a Lei bamboo shoot production area, and its soil is classified as Ferralic Cambisol $(F A O, 2006)$. The region is located on the sunny side of the hill with a slope of $10-15^{\circ}$. The canopy closure is $80-90 \%$, and no other plants grow on the surface. The plot has undergone shortterm intensive management for two years. The BCF system has been operating for six years, and only selective logging is conducted to maintain an appropriate canopy density. The BCF area is approximately 15 ha and contains 1500-1800 chickens per hectare.

\subsection{Experimental design and soil sampling}


In this study, we characterized the changes in grazing intensity as the differences in grazing distance from the hen house, which is based on the chickens' habits. This technique is a common method for estimating plant and animal density and abundance (Stumpp et al., 2005; Manthey \& Peper, 2010). A total of four sites $(5,15,25$, and $35 \mathrm{~m}$ distance from the hen house) and one control site (CK; $>60 \mathrm{~m}$ from the hen house) were assessed in the same manner. A pure bamboo forest located $>60 \mathrm{~m}$ from the hen house was selected as the control site as its environmental conditions and initial soil properties were similar to those of the BCF forest.

For all sites, five $2 \times 2 \mathrm{~m}$ sampling plots were randomly selected in an S shape along the slope direction. Three samples from the same soil layer $(0-20 \mathrm{~cm})$ of each sampling plot were collected in mid-May 2019 and carefully mixed to form five composite samples. The composite samples were then transferred into a sterile sealed bag, placed on ice, and transported to the laboratory for pretreatment. After the samples were thoroughly mixed and hand-sieved through a 2-mm sieve, a portion of each fresh soil sample was stored at $4{ }^{\circ} \mathrm{C}$ and $-80{ }^{\circ} \mathrm{C}$ for further analysis. The remaining portion of the soil sample was air-dried and stored for determining soil properties, $\mathrm{P}$ fractions, and phosphatase activity.

\subsection{Soil basic properties}

Soil $\mathrm{pH}$ was measured from a soil suspension (1:2.5, w/v) using a pH meter (PHS-3E; REX, China). The soil cation exchange capacity (CEC) was determined via the ammonium acetate method (Chapman, 1965). Briefly, $2 \mathrm{~g}$ of air-dried soil was placed in a $100 \mathrm{ml}$ centrifuge tube and then centrifuged at 4000 $\mathrm{rpm}$ for $5 \mathrm{~min}$ with $50 \mathrm{ml}$ of $1 \mathrm{~mol} \cdot \mathrm{L}^{-1} \mathrm{NH}_{4} \mathrm{OAc}$ solution. The supernatant was then discarded, and the above process was repeated 3-4 times. The soil sample was then rinsed 4-5 times with $25 \mathrm{ml} 95 \%$ ethanol. After discarding the ethanol solution, $1 \mathrm{~g}$ solid magnesium chloride and $2 \mathrm{ml}$ liquid paraffin were added to the soil, and the $\mathrm{NH}_{4}{ }^{+}$content was determined using a Kjeldahl nitrogen analyzer (UDK159; Velp Scientifica; Italy). Soil organic carbon (SOC) was measured using a TOC analyzer (Multi N/C 3100; Analytik Jena, Germany), and soil alkali-hydrolysable nitrogen (AN) was determined following the alkalidiffusion method (Bremner et al., 1996). Soil available potassium (AK) was extracted with $1 \mathrm{~mol} \cdot \mathrm{L}^{-1}$ $\mathrm{CH}_{3} \mathrm{COONH}_{4}$ at $\mathrm{pH} 7$ and measured by flame photometry (FP6410 INESA, China).

\subsection{Fractionation procedure for soil $P$}

The continuous extraction method proposed by Hedley et al. (1982) and modified by Tissen and Moir (1993) was used to fractionate the soil $P$ in this study. Briefly, the $P$ fractions were extracted from $0.5 \mathrm{~g}$ air-dried soil in a $50 \mathrm{ml}$ centrifuge tube via the following steps: (1) two $9 \times 62 \mathrm{~mm}$ resin strips and $30 \mathrm{ml}$ distilled water were added to the centrifuge tubes, and the phosphorus in the resin strips was extracted with $0.5 \mathrm{M} \mathrm{HCl}$ after $16 \mathrm{~h}$ of shaking at $160 \mathrm{rpm}$ (Resin-Pi); (2) after removing the aqueous solution, $30 \mathrm{ml}$ $0.5 \mathrm{M} \mathrm{NaHCO}_{3}$ at $\mathrm{pH} 8.5$ was added and shaken for $16 \mathrm{~h}$ to extract $\mathrm{NaHCO}_{3}-\mathrm{P}$; (3) $30 \mathrm{ml} 0.1 \mathrm{M} \mathrm{NaOH}$ was added and shaken for $16 \mathrm{~h}$ to extract $\mathrm{NaOH}-\mathrm{P}$; (4) $1 \mathrm{M} \mathrm{HCl}-\mathrm{Pi}$ was extracted by adding $30 \mathrm{ml} 1 \mathrm{M} \mathrm{HCl}$ to 
the centrifuge tube and shaken for $16 \mathrm{~h}$; (5) the soil residue was further extracted with $15 \mathrm{ml}$ concentrated $\mathrm{HCl}$ at $80^{\circ} \mathrm{C}$ (conc. $\mathrm{HCl}-\mathrm{P}$ ); and finally, (6) $\mathrm{P}$ was extracted by boiling the soil residue in $8 \mathrm{ml}$ concentrated $\mathrm{H}_{2} \mathrm{SO}_{4}$ and 10 drops of $\mathrm{HClO}_{4}$ (Residual-P). The concentrations of $\mathrm{Pi}$ in the different extracts (Resin-Pi, 1 $\mathrm{M} \mathrm{HCl}-\mathrm{Pi}$, and conc. $\mathrm{HCl}-\mathrm{P}$ ) were determined via the method described by Murphy and Riley (Murphy \& Riley, 1962). The extracts that were obtained using $\mathrm{NaHCO}_{3}$ and $\mathrm{NaOH}$ were first acidified with $6 \mathrm{ml}$ and $1.6 \mathrm{ml} 0.9 \mathrm{M} \mathrm{H}_{2} \mathrm{SO}_{4}$, respectively, before determining the Pi concentrations via the method by Murphy and Riley. The total $\mathrm{P}$ concentrations of the different extracts $\left(\mathrm{NaHCO}_{3}-\mathrm{P}, \mathrm{NaOH}-\mathrm{P}\right.$, and conc. $\left.\mathrm{HCl}-\mathrm{P}\right)$ were determined by the ammonium persulfate digestion method. Finally, the Po concentration of the different extracts $\left(\mathrm{NaHCO}_{3}-\mathrm{P}, \mathrm{NaOH}-\mathrm{P}\right.$, and conc. $\left.\mathrm{HCl}-\mathrm{P}\right)$ was calculated as the difference between total $\mathrm{P}$ and $\mathrm{Pi}$.

\subsection{ACP and ALP activities}

ACP (EC 3.1.3.2) and ALP (EC 3.1.3.1) activities were determined following a modified method as described by Tabtabai and Bremner (1969). Briefly, $0.5 \mathrm{ml}$ toluene was added to $1 \mathrm{~g}$ of air-dried soil and then shaken for 15 min. A modified universal buffer ( $\mathrm{pH} 6.5$ for ACP and $\mathrm{pH} 11.0$ for ALP) was then added, and the sample was subsequently incubated at $37^{\circ} \mathrm{C}$ for $24 \mathrm{~h}$. The formation of $p$-nitrophenol was determined at $400 \mathrm{~nm}$ after the termination of the enzymatic reaction. ACP and ALP activities were expressed as $\mu \mathrm{mol}$ pNP g $\mathrm{g}^{-1}$ soil $\mathrm{d}^{-1}$.

\subsection{Soil DNA extraction, PCR, and high-throughput sequencing}

The Fast DNA ${ }^{\circledR}$ Spin Kit for Soil (MP Biomedicals, U.S.A) was used to extract the soil DNA according to the manufacturer's instructions. We used 1\% agarose gel electrophoresis to detect the DNA extraction quality and NanoDrop2000 to determine the DNA concentration and purity. Primers 338F (5'ACTCCTACGGGAGGCAGCAG-3') and 806R (5'-GGACTACHVGGGTWTCTAAT-3') were used to amplify the V3-V4 hypervariable region sequences of the bacterial 16S rRNA gene (Wang et al., 2018). Polymerase chain reaction (PCR) amplification, library construction, and Illumina Miseq sequencing were performed by Shanghai Majorbio Bio-pharm Technology Co., Ltd.

\subsection{Bioinformatic analysis}

Trimmomatic $v 0.32$ was used to perform quality control on the original sequencing sequence (Lohse et al., 2012). The quality control sequence was performed double-end splicing using FLASH v 1.2.11 (Magoč et al., 2011). Chimeras $16 \mathrm{~S}$ sequences were removed, and high-quality nucleic acid sequences were clustered into operational taxonomic units (OTUs) based on 97\% similarity using UPARSE v 7.1 (Wang et al., 2017). The alignment threshold was 70\%, and each sequence was classified and annotated using the 
RDP classifier (http://rdp.cme.msu.edu/). The phosphobacterial species were identified by database screening.

\subsection{Statistical analysis}

We used the SPSS statistical software package version 21.0 for Windows to perform the statistical analyses in this study. A one-way analysis of variance (ANOVA) and Duncan's test were used to identify the significant differences $(p<0.05)$ between the soil samples. The alpha diversity (Shannon, Chao1, and Observed species index) of the soil bacterial communities was calculated using the Vegan package of $\mathrm{R}$ (ver. 3.6.3). To determine the differences in soil bacterial communities between the different sites, we used QIIME to conduct a principal coordinate analysis (PCOA) based on Unifrac distance. We conducted a redundancy analysis (RDA) on soil environmental factors and bacterial communities, which was visualized by the Vegan and ggplot2 packages of R. Finally, a Pearson's correlation analysis was used to test the correlation between soil phosphobacteria and $\mathrm{P}$ fractions.

\section{Results}

\subsection{Soil properties}

The BCF soil showed significantly different chemical properties to that of the control soil (Table 1). Soil $\mathrm{pH}, \mathrm{CEC}, \mathrm{SOC}, \mathrm{TN}, \mathrm{AN}$, and AK were significantly higher in BCF $(p<0.05)$ than in the control. The soil $\mathrm{pH}$, CEC, TN, AN, and AK were highest at the 5-m site; however, we observed no significant difference in SOC across the different sites $(p>0.05)$. The soil total $\mathrm{P}(\mathrm{Pt})$ content in the BCF was significantly higher than that of the control $(p<0.05)$ and increased with increasing grazing density. Pi accounted for approximately $60-82 \%$ of $\mathrm{Pt}$ and also showed similar variability to that of $\mathrm{Pt}$. The $\mathrm{Pi} / \mathrm{Pt}$ value significantly increased with increasing grazing density $(p<0.05)$. Compared with the control, the BCF soil had a significantly higher total Po content but lower Po/Pt values $(p<0.05)$. 
Soil properties at different grazing distances from the hen house.

\begin{tabular}{|c|c|c|c|c|c|}
\hline & $5-m$ & $15-m$ & $25-m$ & $35-m$ & CK \\
\hline $\mathrm{pH}$ & $\mathrm{b}_{6} 6.69 \pm 0.21 \mathrm{a}$ & $5.75 \pm 0.08 b$ & $5.66 \pm 0.12 b$ & $5.77 \pm 0.14 b$ & $5.02 \pm 0.06 c$ \\
\hline $\begin{array}{l}\text { CEC }\left(\mathrm{cmol}^{\prime} \mathrm{kg}^{-}\right. \\
\left.{ }^{1}\right)\end{array}$ & $18.07 \pm 1.30 a$ & $17.62 \pm 0.67 a$ & $15.35 \pm 0.96 b$ & $15.25 \pm 0.80 b$ & $13.75 \pm 0.43 c$ \\
\hline $\operatorname{sOC}\left(g \cdot \mathrm{kg}^{-1}\right)$ & $41.97 \pm 2.36 a$ & $42.72 \pm 3.20 \mathrm{a}$ & $\begin{array}{l}41.81 \pm \\
30.97 a\end{array}$ & $41.35 \pm 2.99 a$ & $36.67 \pm 1.36 b$ \\
\hline $\mathrm{TN}\left(\mathrm{g} \cdot \mathrm{kg}^{-1}\right)$ & $3.19 \pm 0.32 a$ & $2.97 \pm 0.12 a$ & $2.27 \pm 0.27 b$ & $2.46 \pm 0.16 b$ & $1.77 \pm 0.12 c$ \\
\hline AN $\left(\mathrm{mg} \cdot \mathrm{kg}^{-1}\right)$ & $\begin{array}{l}214.97 \pm \\
4.96 a\end{array}$ & $\begin{array}{l}220.66 \pm \\
3.66 a\end{array}$ & $\begin{array}{l}184.43 \pm \\
8.35 b\end{array}$ & $\begin{array}{l}176.69 \pm \\
4.98 \mathrm{~b}\end{array}$ & $\begin{array}{l}146.67 \pm \\
9.55 \mathrm{c}\end{array}$ \\
\hline AK $\left(\mathrm{mg} \cdot \mathrm{kg}^{-1}\right)$ & $\begin{array}{l}591.64 \pm \\
34.78 a\end{array}$ & $\begin{array}{l}402.22 \pm \\
10.48 \mathrm{~b}\end{array}$ & $\begin{array}{l}381.16 \pm \\
3.10 \mathrm{~b}\end{array}$ & $\begin{array}{l}394.32 \pm \\
8.30 \mathrm{~b}\end{array}$ & $\begin{array}{l}200.27 \pm \\
4.77 \mathrm{c}\end{array}$ \\
\hline $\begin{array}{l}\text { a Total P }\left(\mathrm{g} \cdot \mathrm{kg}^{-}\right. \\
\left.{ }^{1}\right)\end{array}$ & $2.56 \pm 0.08 a$ & $2.02 \pm 0.05 b$ & $1.72 \pm 0.09 c$ & $1.62 \pm 0.08 d$ & $0.93 \pm 0.03 e$ \\
\hline $\begin{array}{l}\text { Total Pi }\left(\mathrm{g} \cdot \mathrm{kg}^{-}\right. \\
\left.{ }^{1}\right)\end{array}$ & $2.10 \pm 0.08 a$ & $1.48 \pm 0.04 b$ & $1.31 \pm 0.08 c$ & $1.22 \pm 0.06 d$ & $0.56 \pm 0.03 e$ \\
\hline $\mathrm{Pi} / \mathrm{Pt}(\%)$ & $82.00 \pm 1.29 a$ & $73.04 \pm 1.34 c$ & $75.97 \pm 1.35 b$ & $74.88 \pm 1.64 b$ & $60.61 \pm 1.31 d$ \\
\hline $\begin{array}{l}\text { Total Po }\left(\mathrm{g} \cdot \mathrm{kg}^{-}\right. \\
\text {1) }\end{array}$ & $0.45 \pm 0.03 b$ & $0.54 \pm 0.03 a$ & $0.41 \pm 0.03 c$ & $0.40 \pm 0.04 c$ & $0.36 \pm 0.02 d$ \\
\hline Po/Pt (\%) & $17.65 \pm 1.28 d$ & $26.57 \pm 1.33 b$ & $23.64 \pm 1.35 c$ & $24.72 \pm 1.64 c$ & $38.54 \pm 1.29 a$ \\
\hline \multicolumn{6}{|c|}{$\begin{array}{l}\text { a Total } \mathrm{P} \text { is the cumulative value of all } \mathrm{P} \text { fractions; total } \mathrm{Pi} \text { is the sum of Resin-Pi, } \mathrm{NaHCO}_{3}-\mathrm{Pi}, \mathrm{NaOH}-\mathrm{Pi} \text {, } \\
1 \mathrm{M} \mathrm{HCl}-\mathrm{Pi} \text {, and Conc. } \mathrm{HCl}-\mathrm{Pi} \text {; and Total } \mathrm{Po} \text { is the sum of } \mathrm{NaHCO}_{3}-\mathrm{Po}, \mathrm{NaOH}-\mathrm{Po} \text {, and } \mathrm{Conc} \text {. } \mathrm{HCl}-\mathrm{Po} \text {. }\end{array}$} \\
\hline $\begin{array}{l}\text { b Values are e } \\
\text { lowercase lett }\end{array}$ & sed as me & 5) \pm standar & $\begin{array}{l}\text { r. Values in } \\
\text { other grazir }\end{array}$ & ame row with & $\begin{array}{l}\text { ferent } \\
\text { uncan's test). }\end{array}$ \\
\hline
\end{tabular}

\subsection{Soil $P$ fractions and phosphatase activity}

Our results showed that the BCF system significantly affected the relative content of each $\mathrm{P}$ fraction (Figure 2). The relative content of labile P was approximately $26-28 \%$ of Pt. In comparison, the relative content of moderately labile $\mathrm{P}$ was $52-64 \%$ of $\mathrm{Pt}$, which gradually increased with increasing grazing density. Furthermore, $\mathrm{NaHCO}_{3}$-Pi contributed the largest proportion to labile $\mathrm{P}$ in the soil, accounting for 
approximately 44-50\%. Moreover, the relative content of Resin-Pi gradually increased with increasing grazing density, while the proportion of $\mathrm{NaHCO}_{3}-\mathrm{Po}$ in labile $\mathrm{P}$ gradually decreased. Chicken farming had altered the composition of moderately labile $\mathrm{P}$. The proportion of $\mathrm{NaOH}$-extracted $\mathrm{P}$ in moderately labile $\mathrm{P}$ decreased gradually with increasing grazing density from $86 \%$ to $40 \%$. Correspondingly, the proportion of $1 \mathrm{M} \mathrm{HCl}-\mathrm{Pi}$ increased with decreasing grazing distance; the proportion at $5 \mathrm{~m}$ was higher than those of the other sites and the control group by 1.36-fold and 13.54-fold, respectively. Compared with the control, chicken farming reduced the relative content of sparingly labile $P$, but the variability in its composition was limited (the relative content of conc. $\mathrm{HCl}$-Pi varied within the range of $59-68 \%$ across all sites).

Labile $\mathrm{P}$, moderately labile $\mathrm{P}$, and sparingly labile $\mathrm{P}$ increased significantly with increasing grazing density $(p<0.05)$ (Table 2). The $\mathrm{Pi}$ fraction (Resin-Pi and $\mathrm{NaHCO}_{3}-\mathrm{Pi}$ ) in labile $\mathrm{P}$ especially increased with increasing grazing density, and the maximum and minimum soil values of $\mathrm{NaHCO}_{3}-\mathrm{Pi}$ and Resin-Pi occurred at the 5-m site and the control, respectively. Compared with the control, we observed no significant difference in the Po fraction in labile $\mathrm{P}$ at 25 and $35 \mathrm{~m}\left(\mathrm{NaHCO}_{3}-\mathrm{Po}\right)(p>0.05)$. In moderately labile $\mathrm{P}$, the maximum and minimum $\mathrm{P}$ contents extracted by $\mathrm{NaOH}$ were observed at $15 \mathrm{~m}$ and the control, respectively. Although both $\mathrm{NaOH}-\mathrm{Pi}$ and $\mathrm{NaOH}-\mathrm{Po}$ values at $5 \mathrm{~m}$ were significantly lower than those at $15 \mathrm{~m}(p<0.05)$, the $1 \mathrm{M} \mathrm{HCl}-\mathrm{Pi}$ at $5 \mathrm{~m}$ increased by $116.41 \%$ and $1354.41 \%$ compared with the $15-\mathrm{m}$ site and the control, respectively. In sparingly labile $\mathrm{P}$, the soil at $5 \mathrm{~m}$ had significantly higher conc. $\mathrm{HCl}-\mathrm{Pi}$ than the soils at the other sites and the control $(p<0.05)$. The conc. HCl-Po trend was not consistent with that of conc. HCl-Pi, except for $15 \mathrm{~m}$; however, the values were not significantly different to those of the other sites and the control $(p>0.05)$. 
Table 2

Phosphorus $(P)$ sequential fractionation $(\mathrm{g} \cdot \mathrm{kg}-1)$ in the bamboo forest soil at different grazing distances from the hen house.

\begin{tabular}{|c|c|c|c|c|c|}
\hline P fraction & $5-m$ & $15-m$ & $25-m$ & $35-m$ & CK \\
\hline \multicolumn{6}{|l|}{${ }^{a}$ Labile P } \\
\hline Resin-Pi & $\mathrm{b}_{0} 0.20 \pm 0.01 \mathrm{a}$ & $\begin{array}{l}0.15 \pm \\
0.01 b\end{array}$ & $0.12 \pm 0.01 \mathrm{c}$ & $0.13 \pm 0.01 \mathrm{c}$ & $0.06 \pm 0.01 d$ \\
\hline $\mathrm{NaHCO}-\mathrm{Pi}$ & $0.34 \pm 0.03 a$ & $\begin{array}{l}0.26 \pm \\
0.02 b\end{array}$ & $0.22 \pm 0.02 c$ & $0.22 \pm 0.02 c$ & $0.12 \pm 0.01 d$ \\
\hline NaHCO3-Po & $0.14 \pm 0.02 a$ & $\begin{array}{l}0.13 \pm \\
0.03 a\end{array}$ & $0.11 \pm 0.01 b$ & $0.09 \pm 0.01 b$ & $0.09 \pm 0.01 b$ \\
\hline$\sum$ Labile P & $0.68 \pm 0.02 a$ & $\begin{array}{l}0.55 \pm \\
0.04 \mathrm{~b}\end{array}$ & $0.45 \pm 0.02 c$ & $0.44 \pm 0.03 c$ & $0.26 \pm 0.02 d$ \\
\hline \multicolumn{6}{|l|}{ Moderately labile P } \\
\hline $\mathrm{NaOH}-\mathrm{Pi}$ & $0.42 \pm 0.03 b$ & $\begin{array}{l}0.45 \pm \\
0.02 a\end{array}$ & $0.37 \pm 0.03 c$ & $0.37 \pm 0.02 c$ & $0.21 \pm 0.02 d$ \\
\hline $\mathrm{NaOH}-\mathrm{Po}$ & $0.24 \pm 0.02 b$ & $\begin{array}{l}0.30 \pm \\
0.02 \mathrm{a}\end{array}$ & $\begin{array}{l}0.23 \pm \\
0.01 \mathrm{ab}\end{array}$ & $0.24 \pm 0.03 b$ & $0.20 \pm 0.02 c$ \\
\hline $1 \mathrm{M} \mathrm{HCl}-\mathrm{Pi}$ & $0.99 \pm 0.08 a$ & $\begin{array}{l}0.46 \pm \\
0.02 \mathrm{~b}\end{array}$ & $0.45 \pm 0.04 b$ & $0.36 \pm 0.02 c$ & $0.07 \pm 0.01 d$ \\
\hline$\sum_{P}$ Moderately labile & $1.65 \pm 0.05 a$ & $\begin{array}{l}1.21 \pm \\
0.04 \mathrm{~b}\end{array}$ & $1.05 \pm 0.08 c$ & $0.97 \pm 0.07 d$ & $0.48 \pm 0.03 e$ \\
\hline \multicolumn{6}{|l|}{ Sparingly labile P } \\
\hline conc.HCl-Pi & $0.16 \pm 0.01 a$ & $\begin{array}{l}0.15 \pm \\
0.01 \mathrm{~b}\end{array}$ & $\begin{array}{l}0.15 \pm \\
0.01 \mathrm{ab}\end{array}$ & $0.13 \pm 0.01 \mathrm{c}$ & $0.11 \pm 0.01 d$ \\
\hline conc.HCl-Po & $0.08 \pm 0.01 b$ & $\begin{array}{l}0.11 \pm \\
0.01 \mathrm{a}\end{array}$ & $0.07 \pm 0.02 b$ & $0.07 \pm 0.02 b$ & $0.07 \pm 0.01 b$ \\
\hline$\sum$ Sparingly labile $\mathrm{P}$ & $\begin{array}{l}0.24 \pm \\
0.01 \mathrm{ab}\end{array}$ & $\begin{array}{l}0.25 \pm \\
0.01 a\end{array}$ & $0.22 \pm 0.02 b c$ & $0.20 \pm 0.01 \mathrm{c}$ & $0.18 \pm 0.01 d$ \\
\hline Non-labile P & & & & & \\
\hline
\end{tabular}

\footnotetext{
a P fractions were classified according to Liao et al. (2020) and Crews and Brookes (2014).

${ }^{b}$ Values are expressed as the mean $(n=5) \pm$ standard error. Values in the same row with different lowercase letters indicate significant differences to the other grazing sites at $\mathrm{P}<0.05$ (Duncan's test).
} 


\begin{tabular}{|llllll|}
\hline P fraction & $5-\mathrm{m}$ & $\mathbf{1 5 - m}$ & $25-\mathrm{m}$ & $35-\mathrm{m}$ & CK \\
\hline Residual-Pt & $0.01 \pm 0.00 \mathrm{a}$ & $\begin{array}{l}0.01 \pm \\
0.00 \mathrm{~b}\end{array}$ & $0.01 \pm 0.00 \mathrm{c}$ & $0.01 \pm 0.00 \mathrm{c}$ & $0.01 \pm 0.00 \mathrm{~b}$ \\
\hline a $\mathrm{P}$ fractions were classified according to Liao et al. (2020) and Crews and Brookes (2014). \\
\hline $\begin{array}{l}\text { b Values are expressed as the mean }(\mathrm{n}=5) \pm \text { standard error. Values in the same row with different } \\
\text { lowercase letters indicate significant differences to the other grazing sites at } \mathrm{P}<0.05 \text { (Duncan's test). }\end{array}$ \\
\hline
\end{tabular}

Chicken farming affected the activity of ACP and ALP in soil (Figure 3). The activity of soil ACP was significantly higher in BCF than in the control $(p<0.05)$ (Figure 3a), but no significant differences were observed between the different sites $(p>0.05)$. The highest ALP activity was observed at the $5-\mathrm{m}$ site $\left(9.97 \mu \mathrm{mol} p \mathrm{NP} \mathrm{g}^{-1}\right.$ soil d $\left.^{-1}\right)$, which was significantly higher than the other sites and the control $(p<0.05)$ (Figure $3 \mathrm{~b}$ ). Compared with the control, the ALP activity at 15,25 , and $35 \mathrm{~m}$ significantly increased by $66.43 \%, 26.96 \%$, and $69.61 \%$, respectively $(p<0.05)$.

\subsection{Soil bacterial community structure}

Except for $25 \mathrm{~m}$, we observed no significant difference between the alpha diversity index of the different sites and the control $(p>0.05)$ (Figure S1). We used a PCoA to compare the bacterial communities between the sites and the control based on unweighted and weighted Unifrac distances (Figure S2). The unweighted PCoA clearly separated the BCF and control bacterial communities (Figure S2a). Moreover, the 15-, 25-, and 35-m sites were tightly clustered, whereas the 5-m site notably deviated from the group. The sample aggregation in the weighted analysis was similar to that in the unweighted analysis. The combined axis of PCo1, PCo2, and PCo3 accounted for $28.94 \%$ and $74.81 \%$ of the total change in the unweighted and weighted PCOA, respectively. The ANOSIM results also revealed significant differences in the bacterial community composition between the different sites $(p<0.05)$.

In all the soil samples, the dominant bacteria phyla with average relative abundances of $>1 \%$ were Proteobacteria (38.91\%), Acidobacteria (16.27\%), Actinobacteria (10.61\%), Bacteroidetes (7.89\%), Chloroflexi (7.05\%), TM7 (6.11\%), Gemmatimonadetes (3.71\%), AD3 (1.67\%), Firmicutes (1.08\%), and Verrucomicrobia (1.07\%) (Figure S3). We performed a one-way ANOVA to compare the individual taxa at the phylum level (Figure 4). Compared with the control, the relative abundance of Proteobacteria and TM7 had significantly increased in BCF $(p<0.05)$, except at the $5-\mathrm{m}$ site. The relative abundances of Acidobacteria and Bacteroidetes in the 15-, 25-, and 35-m sites did not significantly differ from that of the control $(p>0.05)$. However, their relative abundances in the $5-m$ site were significantly different to those of the other sites and the control $(p<0.05)$. The relative abundance of Gemmatimonadetes was significantly higher at the $5-\mathrm{m}$ and $15-\mathrm{m}$ sites compared with the $25-\mathrm{m}$ and $35-\mathrm{m}$ sites and the control $(p<$ 0.05). Soils under BCF conditions had a lower relative abundance of AD3 compared with the control soil 
$(p<0.05)$. Furthermore, the relative abundance of Firmicutes was similar in the BCF sites and the control, except at $5 \mathrm{~m}(p>0.05)$.

Seven dominant phosphobacteria genera (average relative abundance $>0.1 \%$ ) were detected in the topsoil of the BCF sites and the control, including Flavobacterium (1.55\%), Burkholderia $(0.59 \%)$, Pseudomonas (0.40\%), Bacillus (0.30\%), Streptomyces (0.21\%), Arthrobacter $(0.20 \%)$, and Paenibacillus $(0.10 \%)$. The relative abundance of Flavobacterium at the 5 -m site was significantly higher than those of the other sites and the control $(p<0.05)$ (Table 3$)$. Flavobacterium abundances at 15,25 , and $35 \mathrm{~m}$ were $0.55,1.32$, and 2.12 times the control values, but the differences were not significant $(p>0.05)$.

Compared with the control, the relative abundance of Burkholderia was significantly lower in the 5-m site $(p<0.05)$ but showed no significant differences at 15 and $25 \mathrm{~m}(p>0.05)$. The relative abundance of Pseudomonas, Streptomyces, Arthrobacter, and Paenibacillus increased significantly in the BCF soils, but only the relative abundances of Pseudomonas and Paenibacillus at 25-m significantly differed from the other sites $(p<0.05)$. Furthermore, we observed no clear difference in the relative abundance of Bacillus between the different sites and the control.

Table 3

Relative abundances of the dominant phosphobacteria genera (average relative abundance $>0.1 \%$ ) in soil at different distances from the hen house.

\begin{tabular}{|c|c|c|c|c|c|c|}
\hline phyla & genera & $5-m$ & $15-m$ & $25-\mathrm{m}$ & $35-\mathrm{m}$ & CK \\
\hline Bacteroidetes & Flavobacterium & $\begin{array}{l}3.80 \pm \\
1.57 \mathrm{a}\end{array}$ & $\begin{array}{l}0.49 \pm \\
0.21 \mathrm{~b}\end{array}$ & $\begin{array}{l}0.73 \pm \\
0.35 b\end{array}$ & $\begin{array}{l}0.99 \pm \\
0.25 b\end{array}$ & $\begin{array}{l}0.32 \pm \\
0.13 b\end{array}$ \\
\hline \multirow[t]{2}{*}{ Proteobacteria } & Burkholderia & $\begin{array}{l}0.41 \pm \\
0.12 \mathrm{c}\end{array}$ & $\begin{array}{l}0.81 \pm \\
0.21 \mathrm{a}\end{array}$ & $\begin{array}{l}0.75 \pm \\
0.16 a b\end{array}$ & $\begin{array}{l}0.55 \pm \\
0.19 b\end{array}$ & $\begin{array}{l}0.83 \pm \\
0.21 \mathrm{a}\end{array}$ \\
\hline & Pseudomonas & $\begin{array}{l}0.42 \pm \\
0.09 b\end{array}$ & $\begin{array}{l}0.38 \pm \\
0.07 \mathrm{~b}\end{array}$ & $\begin{array}{l}0.62 \pm \\
0.16 a\end{array}$ & $\begin{array}{l}0.35 \pm \\
0.10 \mathrm{~b}\end{array}$ & $\begin{array}{l}0.13 \pm \\
0.04 c\end{array}$ \\
\hline \multirow[t]{2}{*}{ Actinobacteria } & Streptomyces & $\begin{array}{l}0.20 \pm \\
0.05 \mathrm{~b}\end{array}$ & $\begin{array}{l}0.32 \pm \\
0.07 a\end{array}$ & $\begin{array}{l}0.20 \pm \\
0.04 \mathrm{~b}\end{array}$ & $\begin{array}{l}0.23 \pm \\
0.03 \mathrm{~b}\end{array}$ & $\begin{array}{l}0.10 \pm \\
0.04 c\end{array}$ \\
\hline & Arthrobacter & $\begin{array}{l}0.29 \pm \\
0.11 \mathrm{a}\end{array}$ & $\begin{array}{l}0.23 \pm \\
0.11 \mathrm{a}\end{array}$ & $\begin{array}{l}0.22 \pm \\
0.20 a\end{array}$ & $\begin{array}{l}0.16 \pm \\
0.06 \mathrm{ab}\end{array}$ & $\begin{array}{l}0.02 \pm \\
0.02 \mathrm{~b}\end{array}$ \\
\hline \multirow[t]{2}{*}{ Firmicutes } & Bacillus & $\begin{array}{l}0.26 \pm \\
0.08 a\end{array}$ & $\begin{array}{l}0.35 \pm \\
0.12 a\end{array}$ & $\begin{array}{l}0.27 \pm \\
0.03 a\end{array}$ & $\begin{array}{l}0.35 \pm \\
0.05 a\end{array}$ & $\begin{array}{l}0.35 \pm \\
0.15 a\end{array}$ \\
\hline & Paenibacillus & $\begin{array}{l}0.07 \pm \\
0.02 \mathrm{c}\end{array}$ & $\begin{array}{l}0.11 \pm \\
0.02 \mathrm{~b}\end{array}$ & $\begin{array}{l}0.14 \pm \\
0.02 \mathrm{a}\end{array}$ & $\begin{array}{l}0.13 \pm \\
0.01 \mathrm{ab}\end{array}$ & $\begin{array}{l}0.05 \pm \\
0.01 d\end{array}$ \\
\hline
\end{tabular}

\subsection{Correlating P fractions with the bacterial community}


The results of the Pearson correlation analysis inferred the relationship between soil parameters and the dominant bacteria phyla (Figure S4). Among the different soil chemical properties, Proteobacteria and TM7 only significantly positively correlated with the SOC content. In contrast, except for SOC, Bacteroidetes significantly positively correlated with the other soil chemical variables ( $\mathrm{pH}, \mathrm{CEC}, \mathrm{TN}, \mathrm{AN}$, and AK). Gemmatimonadetes significantly positively correlated with $\mathrm{pH}, \mathrm{CEC}, \mathrm{SOC}, \mathrm{TN}, \mathrm{AN}$, and AK. However, contrary to Gemmatimonadetes, AD3 significantly negatively correlated with all the soil basic properties. Furthermore, Proteobacteria and TM7 showed significant and extremely significant positive correlations with $\mathrm{NaOH}-\mathrm{P}$, respectively. We also observed a strong positive relationship between Bacteroidetes and all the Pi fractions. Gemmatimonadetes also showed a significant positive correlation with the $\mathrm{Pi}$ fractions, except conc. $\mathrm{HCl}-\mathrm{Pi}$. Actinobacteria showed a strong significant negative correlation with Resin-Pi and $1 \mathrm{M} \mathrm{HCl}-\mathrm{Pi}$ and a significant negative correlation with $\mathrm{NaHCO}_{3}$-Pi and conc. $\mathrm{HCl}-\mathrm{Pi}$. Moreover, $A D 3$ showed a strong significant negative relationship with the Pi fractions and a significant negative correlation with $\mathrm{NaHCO}_{3}$-Po and $\mathrm{NaOH}-\mathrm{Po}$.

The relative abundances of Flavobacterium, Pseudomonas, Streptomyces, Arthrobacter, and Paenibacillus were mostly correlated with the changes in P fractions (Figure 5). Flavobacterium showed a significant positive correlation with Resin-Pi and a strong significant positive correlation with $\mathrm{NaHCO}_{3}-\mathrm{Pi}$ and $1 \mathrm{M} \mathrm{HCl}-\mathrm{Pi}$. Pseudomonas significantly positively correlated with Resin- $\mathrm{Pi}, \mathrm{NaHCO}_{3}-\mathrm{Pi}$, and $1 \mathrm{M} \mathrm{HCl}-$ $\mathrm{Pi}$, and showed a strong significant positive correlation with $\mathrm{NaOH}-\mathrm{Pi}$ and conc. $\mathrm{HCl}-\mathrm{Pi}$. Streptomyces significantly positively correlated with Resin-Pi, $\mathrm{NaHCO}_{3}-\mathrm{Pi}$, conc. $\mathrm{HCl}-\mathrm{Pi}$, and conc. $\mathrm{HCl}-\mathrm{Po}$, and showed a strong significant correlation with $\mathrm{NaOH}-\mathrm{Pi}$ and $\mathrm{NaOH}-\mathrm{Po}$. Arthrobacter showed a strong significant correlation with Resin- $\mathrm{Pi}, \mathrm{NaHCO}_{3}-\mathrm{Pi}, 1 \mathrm{M} \mathrm{HCl}-\mathrm{Pi}$, and conc. $\mathrm{HCl}-\mathrm{Pi}$, and a significant positive correlation with $\mathrm{NaOH}-\mathrm{Pi}$. Paenibacillus only significantly correlated with $\mathrm{NaOH}-\mathrm{Pi}$. Burkholderia had a negative correlation with all P fractions, with a strong significant negative correlation with $\mathrm{Resin}-\mathrm{Pi}, \mathrm{NaHCO}_{3}-\mathrm{Pi}$, and $1 \mathrm{M} \mathrm{HCl}-\mathrm{Pi}$, and a significant negative correlation with $\mathrm{NaOH}-\mathrm{Po}$ and conc. $\mathrm{HCl}-\mathrm{Pi}$.

The RDA showed that the soil chemical properties and P fractions explained $44.79 \%$ of the variations in soil bacterial community structure (Figure 6). According to the Monte Carlo permutation test (permutation = 999), the Pi fractions, Po fractions (except conc. $\mathrm{HCl}-\mathrm{P}$ ), soil properties, and phosphatase were significantly correlated with the structure of bacterial communities. In Figure 6, a longer arrow represents a stronger relationship between the soil variables and bacterial community composition. Therefore, according to the variance of $\mathrm{r}^{2}$, Pi fractions had a stronger correlation with bacterial community changes than Po fractions (Table S1). Furthermore, among all soil parameters, AK and pH showed the strongest correlation with the changes in bacterial community $\left(r^{2}=0.963\right.$ and 0.962 , respectively), followed by $1 \mathrm{M}$ $\mathrm{HCl}-\mathrm{Pi}$ and Resin-Pi in the Pi fractions $\left(r^{2}=0.958\right.$ and 0.938 , respectively).

\section{Discussion}

\subsection{Effect of BCF on $\mathrm{P}$ fractions}


Labile $\mathrm{Pi}$ (Resin-Pi and $\mathrm{NaHCO}_{3}-\mathrm{Pi}$ ) is the main source of $\mathrm{P}$ for plant growth and can be directly absorbed and utilized by plants (Fu et al., 2020). In our study, we found that the soil labile Pi content in BCF increased significantly compared with the control and also increased with higher grazing density. This trend may be attributed to the soil adsorption of P from manure accumulation (Neufeldt et al., 2000). The increase in P content from manure is more significant for labile Pi than other P fractions (Maranguit et al., 2017), as labile Pi typically accounts for $>40 \%$ of the Pt in chicken manure (Yan et al., 2015; Pagliari \& Laboski, 2012). The $\mathrm{NaOH}-\mathrm{Pi}$ in moderately labile $\mathrm{P}$ usually represents the partially dissolved Fe/Al phosphate in the soil solution, as well as phosphate anions adsorbed on the surface of Fe/Al oxides (Cross \& Schlesinger, 2001). Moreover, Fe and Al mineral contents are relatively high in acidic soils ( $\mathrm{pH}<$ 5) (McGroddy et al., 2008); thus, $\mathrm{NaOH}-\mathrm{P}$ generally dominates the composition of moderately labile $\mathrm{P}$ in Subtropical China. However, BCF altered the composition of moderately labile P in this study, and $1 \mathrm{M}$ $\mathrm{HCl}-\mathrm{Pi}$ gradually dominated with increasing grazing density. This observation can be linked to three possible phenomena: 1) the deposition of chicken manure gradually increases soil pH with increasing grazing density (Somda et al., 1997), which reduces the adsorption performance of iron-aluminum oxides (Yan et al., 2019) and prevents it from complexing with more free phosphorus; 2) the stability of $\mathrm{HCl}-$ extracted $\mathrm{P}$ is strongly dependent on soil $\mathrm{pH}$, and $\mathrm{HCl}$-extracted $\mathrm{P}$ pools in high-pH soils tend to contain highly stable calcium phosphate minerals (Hou et al., 2019; Helfenstein et al., 2020); and 3) the higher $\mathrm{Ca}^{2+}$ in chicken manure may complex with dissolved $\mathrm{Pi}$ in the soil to form $1 \mathrm{M} \mathrm{HCl}-\mathrm{Pi}$ (Sugiyama et al., 2016).

Phosphatase is closely related to the transformation of Po and Pi (Amador et al., 1997) and significantly influences P cycling rates in soil (Sardans et al., 2006). In this study, the activities of both ALP and ACP significantly increased in BCF, which may be linked to manure input and litter disturbance by grazing chickens. These processes increase the soil available nutrients (Williams \& Haynes, 1990; Lindsay \& Cunningham, 2009), which stimulates phosphatase activity. Furthermore, ALP at 5-m was significantly higher than that of the other sites, while ACP showed no significant differences. This may be attributed to the $\mathrm{pH}$ sensitivity of amino acid functional groups in the different phosphatases (Dick et al., 2000); ACP activity is known to be much higher in acidic soils, while ALP activity is much higher in alkaline soils (Katsalirou et al., 2016; Luo et al., 2017). Phosphatases are thought to play a major role in the mineralization of Po to Pi (Nannipieri et al., 2012; Tarafdar \& Jungk, 1987). In agreement, we found that the Pi fractions were significantly correlated with both ALP and ACP in this study. However, ALP was only significantly positively correlated with $\mathrm{NaHCO}_{3}$-Po of the Po fractions, as $\mathrm{NaHCO}_{3}$-Po may be more easily hydrolyzed by the enzyme compared with other Po fractions (Luo et al., 2017).

\subsection{Effect of BCF on the P-associated bacterial community structures}

Marcos et al. (2019) found that grazing can alter soil properties by affecting litter decomposition, manure deposition, and soil compaction, thereby altering soil microbial compositions. In this study, we found that 
BCF increased the relative abundance of Proteobacteria, likely owing to an increase in soil available nutrients and carbon (Goldfarb et al., 2011; Fierer \& Jackson, 2006; Fierer et al., 2007). In addition, previous studies have shown that most Proteobacteria and Actinobacteria are oxygen-dependent (Emerson et al., 2010; Hamamura et al., 2006). Therefore, relatively high grazing density can lead to soil compaction, which decreases the soil oxygen content (Martínez \& Zinck, 2004; Shah et al., 2017); this may explain the relatively low abundance of Proteobacteria and Actinobacteria at the 5-m site (Figure 4). Furthermore, Wang et al. (2016) found that the relative abundance of Actinobacteria correlated with the soil C:N ratio. In our study, the TN content increased with increasing grazing density, but SOC showed no significant change, indicating a gradual decrease in the $\mathrm{C}: \mathrm{N}$ ratio. This may be another reason for the significantly lower Actinobacteria abundance at the 5-m site. Bacteroides was more abundant in the BCF soils, especially at $5 \mathrm{~m}$, which may be owing to the high abundance of Bacteroides in the digestive system of chickens under BCF conditions (Zhang et al., 2020). Bacteroides is also involved in the degradation of complex carbohydrates and has been significantly positively correlated with soil respiration (Thomas et al., 2011; Wang et al., 2016). Therefore, the gradual increase in Bacteroides with increasing grazing intensity may aggravate the loss of SOC. Costello (2007) found that members of AD3 have oligotrophic or micronutrient-requiring characteristics. Thus, our results show that chicken farming significantly reduces the relative abundance of $A D 3$, which suggests that BCFs may be able to alleviate soil nutrient deficiency.

In this study, we observed significant differences in the relative abundance of phosphobacteria (e.g., Flavobacterium, Pseudomonas, Streptomyces) between the BCF and control soils. Flavobacterium is a relatively common bacteria (Soltani et al., 2010) that stimulates plant growth and promotes the developmental plasticity of plant roots through auxin production (Verbon \& Liberman, 2016; Zhao et al., 2019). Flavobacterium is also a highly active phosphobacteria that dissolves phosphate by producing organic acids (Nahas, 1996; Cunningham \& Kuiack, 1992). We found that the relative abundance of Flavobacterium was significantly related to $\mathrm{Pi}$ (Resin-Pi, $\mathrm{NaHCO}_{3}-\mathrm{Pi}$, and $1 \mathrm{M} \mathrm{HCl}-\mathrm{Pi}$ ) (Figure 5), which suggests that the bacteria enhances soil $\mathrm{P}$ bioavailability. Moreover, the significant enrichment of Pseudomonas and Arthrobacter in BCF soils may help to mobilize sparingly labile P, as their relative abundances were significantly positively correlated with recalcitrant and labile $P$. The significant positive correlation between Streptomyces and the Pi fraction and the lower labile Po fractions (such as $\mathrm{NaOH}-\mathrm{Po}$ and conc. $\mathrm{HCl}-\mathrm{Po}$ ) suggests that the bacteria was involved in the mineralization of lower labile Po as well as the microbial immobilization of Pi to lower labile Po. Similar results were observed by Battni et al. $(2017 ;$ 2016). In our study, the significant negative correlation between Burkholderia and the P fractions may been linked to the accumulation of chicken manure, which alkalizes the originally acidic soil. Although chicken manure increases the soil P content, a more alkaline soil is known to inhibit the activity of Burkholderia (Pereira et al., 2013; Stopnisek et al., 2014). Bacillus is one of the most important phosphobacteria (Hayat et al., 2010) and has strong resistance to hostile environments (Zhang, 1990). In this study, the relative abundance of Bacillus did not differ significantly between the different sites and the control and was not significantly correlated with soil properties. This suggests that the soil 
environment in the BCF sites did not influence Bacillus activity, which supports its high resistance to changing environments.

\subsection{Effect of BCF on phosphorus availability and sustainable land use}

BCF significantly enhanced the adsorption capacity for cations (CEC) and improved the fertilizer retention capacity in soil (Ge et al., 2014). Additionally, the increased soil CEC under higher grazing densities may be due to the finer soil texture (Elliott et al., 1986; Teague et al., 2011). We observed no significant difference in SOC between the different grazing densities, which may be due to a number of factors: 1 ) higher grazing densities may damage the soil structure, which increases the loss of water-soluble organic carbon (Zhan et al., 2020); 2) the accumulation of chicken manure increases soil pH under higher grazing density, which weakens the adsorption capacity of iron and aluminum oxides and influences the sequestration of passive organic carbon (Yan et al., 2019); and 3) the increase in Pi fractions alleviates $\mathrm{P}$ limitation for soil microbial metabolism, which enhances soil respiration (Spohn \& Schleuss, 2019).

Soil stoichiometry directly reflects the soil's fertility status and indirectly reflects the plant's nutritional status (Fan et al., 2015). Plant leaves with N:P ratios of $<14$ indicate $\mathrm{N}$ limitation for plant growth, while $\mathrm{N}$ :P ratios of $>16$ indicate $P$ limitation (Koerselman \& Meuleman, 1996; Drenovsky \& Richards, 2004). Fan et al. (2015) showed that soil N:P ratios were strongly correlated with plant N:P ratios. This suggests that the different rates of increase of soil $\mathrm{N}$ and $\mathrm{P}$ with increasing grazing density may have impacted plant growth in this study. Additionally, Yang et al. (2017) demonstrated that a decrease in soil N:P exacerbates $\mathrm{N}$ limitation for plant growth and affects the coupled relationship between $\mathrm{N}$ and $\mathrm{P}$ in soil; this further suggests that the reduced soil N:P from excessive grazing may cause $\mathrm{N}$ limitation for plant growth. Furthermore, Tipping et al. (2016) found that lower C:P and C:N ratios may increase the risk of soil nutrient loss. Previous studies have shown that the risk of $\mathrm{P}$ loss in soil is closely related to $\mathrm{P}$ availability (Liu et al., 2012; Stutter \& Richards, 2018; Liu et al., 2019). Therefore, the lower C:N and C:P ratios and the higher labile and moderately labile $\mathrm{P}$ contents under higher grazing densities indicate a possible risk of $\mathrm{P}$ leaching. In our study, the gradual decrease in the relative content of Po, the increased phosphatase activity, and the increased abundance of phosphobacteria with increasing grazing density suggest that chicken farming promotes the mineralization of Po to Pi. However, further long experiments in this ecosystem are required to determine whether the decrease in Po will eventually lead to P deficiency and become a limiting factor in the $P$ cycle.

Among the different soil properties, $\mathrm{pH}$ had the highest impact on bacterial community structure, likely owing to the narrow pH range for optimal bacterial growth (Ragot et al., 2016; Tian et al., 2020). Similar results were observed in previous studies (Geisseler \& Scow, 2014; Zhang et al., 2019). Potassium can activate a large number of enzymes (Dotaniya et al., 2016) and is therefore important for microbial metabolism and growth processes; this also explains the large influence of available potassium on the bacterial community structure. Furthermore, our results revealed a strong association between the Pi 
fractions (especially $1 \mathrm{M} \mathrm{HCl}-\mathrm{Pi}$ and Resin-Pi) and the soil bacterial community structures, which may be due to the dominance of heterotrophic microorganisms that depend on exogenous nutrients for growth (Beauregard et al., 2010). Therefore, unstable P levels in soil can have profound effects on the soil microbial community structure (Zhang et al., 2020; Langenheder \& Prosser, 2008). In addition, under BCF conditions, $\mathrm{Pi}$ fractions (Resin- $\mathrm{Pi}, \mathrm{NaHCO}_{3}-\mathrm{Pi}$, and $1 \mathrm{M} \mathrm{HCl}-\mathrm{Pi}$ ) and $\mathrm{Po}$ fractions ( $\mathrm{NaOH}-\mathrm{Po}$ and conc. $\mathrm{HCl}-$ Po) changed significantly, which affected the relative abundance of phosphobacteria (such as Flavobacterium, Pseudomonas, Streptomyces, and Arthrobacter, Figure 5); this likely further influenced the overall soil microbial composition.

\section{Conclusion}

We found that chicken farming in bamboo forests significantly altered both the soil P distribution and the soil bacterial community structure. Labile and moderately labile $P$ significantly increased with increasing grazing intensity, which suggests that chicken farming effectively enhances soil P bioavailability. Furthermore, grazing intensity could cause the redistribution of soil $\mathrm{P}$ and promote the mineralization of Po, as evidenced by an increase in the relative contents of labile and moderately labile $\mathrm{P}$, a decrease in the relative content of $\mathrm{Po}$, an increase in phosphatase activity, and changes in phosphobacteria abundance. Our results suggest that phosphobacteria regulated the soil P cycle, mineralized lower labile Po (Streptomyces), and converted insoluble phosphate to soluble phosphate (Pseudomonas and Arthrobacter). Overall, our findings indicate that BCF can alleviate P deficiency in subtropical forests and increase the soil $\mathrm{P}$ supply capacity and potential. However, high grazing density or long-term BCF practices can lead to soil nutrient imbalances and P leaching, which impacts the sustainability of BCF systems.

\section{Abbreviations}

BCF: Bamboo-chicken farming; P: Phosphorus; Pt: Total phosphorus; Po: organic phosphorus; Pi: Inorganic phosphorus; ASL: Above sea level; CEC: Cation exchange capacity; SOC: Soil organic carbon; AN: Alkali-hydrolysable nitrogen; AK: Available potassium; TN: Total nitrogen; ACP: Acid phosphatase; ALP: Alkaline phosphatase; PCoA: Principal coordinate analysis; RDA: Redundancy analysis.

\section{Declarations}

\section{Acknowledgements}

Not applicable.

\section{Authors' contributions}


Z.Z. and X.Z. conceived the study. X.G., S.L., X.Z. and C.Y. performed the fieldwork. X.G., F.B and S.L. measured the soil samples and collaborated with data analysis. X.G. drafted the

manuscript and performed statistical analyses. All authors read and approved the final manuscript.

\section{Funding}

This work was supported by the National Key R\&D Program of China [grant number 2018YFD0600105].

\section{Availability of data and materials}

The datasets used and/or analysed during the current study are available from the corresponding author on reasonable request.

\section{Ethics approval and consent to participate}

Not applicable.

\section{Consent for publication}

Not applicable.

\section{Competing interests}

The authors declare that they have no competing interests

\section{References}

1. Amador, J. A., Glucksman, A. M., Lyons, J. B. and Görres, J. H. (1997). Spatial distribution of soil phosphatase activity within a riparian forest. Soil Science, 162, 808-825. https://doi.org/10.1097/00010694-199711000-00005

2. Battini, F., Cristani, C., Giovannett, M. and Agnolucci, I. (2016). Multifunctionality and diversity of culturable bacterial communities strictly associated with spores of the plant beneficial symbiont Rhizophagus intraradices. Microbiological Research, 183, 68-79. https://doi.org/10.1016/j.micres.2015.11.012

3. Battini, F., Grønlund, M., Agnolucci, M., Giovannetti, M. and Jakobsen, I. (2017). Facilitation of phosphorus uptake in maize plants by mycorrhizosphere bacteria. Scientific Reports, 7, 4686. https://doi.org/10.1038/s41598-017-04959-0 
4. Beauregard, M. S., Hamel, C., Atul-Nayyar and St-Arnaud, M. (2010). Long-term phosphorus fertilization impacts soil fungal and bacterial diversity but not AM fungal community in Alfalfa. Microbial Ecology, 59, 379-389. https://doi.org/10.1007/s00248-009-9583-z

5. Beutler, S. J., Pereira, M. G., Loss, A., Perin, A. and Anjos, L. H. C. D. (2015). Humic substances and phosphorus fractions in areas with crop-livestock integration, pasture and natural cerrado vegetation in Goiasás, Brazil. Tropical and Subtropical Agroecosystems, 18, 11-25.

6. Bremner, J. B., Smith, R. J. and Tarrant, G. J. (1996). A meisenheimer rearrangement approach to bridgehead hydroxylated tropane alkaloid derivatives. Tetrahedron Letters, 37, 97-100. https://doi.org/10.1016/0040-4039(95)02082-9

7. Burman, U., Garg, B. K. and Kathju, S. (2009). Effect of Phosphorus application on clusterbean under different intensities of water stress. Journal of Plant Nutrition, 32, 668-680. https://doi.org/10.1080/01904160802715620

8. Cai, C., Fan, S., Liu, G., Wang, S. and Feng, Y. (2018). \esearch and Development Advance of Compound Management of Bamboo Forests. World Bamboo and Rattan, 16, 47-52. https://doi.org/10.13640/j.cnki.wbr.2018.05.011

9. Chapman, H. D. (1965) Cation exchange capacity. In Black, C. A. (Ed.), Methods of Soil Analysis. pp. 891-901. Madison, Wl: American Society of Agronomy.

10. Chen, Y., Chen, G., Liang, Z., Li, R., Ma, H. and Tu, L. (2018). Ten-year nitrogen addition did not significantly affect soil phosphorus

11. fractions in a Pleioblastus amanus plantation. Ecology and Environmental Sciences, 27, 677-684. https://doi.org/10.16258/j.cnki.1674-5906.2018.04.012

12. Costello, E. K. (2007) Molecular phylogenetic characterization of high altitude soil microbial communities and novel, uncultivated bacterial lineages. Boulder: University of Colorado at Boulder.

13. Crews, T. E. and Brookes, P. C. (2014). Changes in soil phosphorus forms through time in perennial versus annual agroecosystems. Agriculture, Ecosystems \& Environment, 184, 168-181. https://doi.org/10.1016/j.agee.2013.11.022

14. Cross, A. F. and Schlesinger, W. H. (2001). Biological and geochemical controls on phosphorus fractions in semiarid soils. Biogeochemistry, 52, 155-172. https://doi.org/10.1023/A:1006437504494

15. Cunningham, J. E. and Kuiack, C. (1992). Production of citric and oxalic acids and solubilization of calcium phosphate by Penicillium bilaii. Applied and Environmental Microbiology, 58, 1451. https://doi.org/10.1002/yea.320080602

16. Dev, I., Ram, A., Ahlawat, S. P., Palsaniya, D. R., Newaj, R., Tewari, R. K., Singh, R., Sridhar, K. B., Dwivedi, R. P., Srivastava, M., Chaturvedi, O. P., Kumar, R. V. and Yadav, R. S. (2017). Bamboo (Dendrocalamus strictus) + sesame (Sesamum indicum) based agroforestry model: A sustainable livelihood option for farmers of semi-arid region. Indian Journal of Agricultural Sciences, 87, 15281534.

17. Dick, W. A., Cheng, L. and Wang, P. (2000). Soil acid and alkaline phosphatase activity as pH adjustment indicators. Soil Biology and Biochemistry, 32, 1915-1919. https://doi.org/10.1016/S0038- 


\section{7(00)00166-8}

18. Dotaniya, M. L., Meena, V. D., BasakRam, B. B. and Meena, S. (2016) Potassium uptake by crops as well as microorganisms. Potassium Solubilizing Microorganisms for Sustainable Agriculture. pp. 267-280. New Delhi: Springer.

19. Drenovsky, R. E. and Richards, J. H. (2004). Critical N:P values: Predicting nutrient deficiencies in desert shrublands. Plant and Soil, 259, 59-69. https://doi.org/10.1023/B:PLS0.0000020945.09809.3d

20. Elliott, H. A., Liberati, M. R. and Huang, C. P. (1986). Competitive adsorption of heavy metals by soils. Journal of Environmental Quality, 15, 214-219. https://doi.org/10.2134/jeq1986.00472425001500030002x

21. Emerson, D., Fleming, E. J. and McBeth, J. M. (2010). Iron-oxidizing bacteria: An environmental and genomic perspective. Annual Review of Microbiology, 64, 561-583. https://doi.org/10.1146/annurev.micro.112408.134208

22. Fan, H., Wu, J., Liu, W., Yuan, Y., Hu, L. and Cai, Q. (2015). Linkages of plant and soil C:N:P stoichiometry and their relationships to forest growth in subtropical plantations. Plant and Soil, 392, 127-138. https://doi.org/10.1007/s11104-015-2444-2

23. FAO (2006). Guidelines for Soil Description, 4rd Edition. Rome, Food and Agriculture Organization of the United Nations.

24. FAO (2010). Global Forest Resources Assessment 2010: Main Report. Roma, Food and Agriculture Organization of the United Nations.

25. Fierer, N. and Jackson, R. B. (2006). The diversity and biogeography of soil bacterial communities. Proceedings of the National Academy of Sciences, 103, 626-631. https://doi.org/10.1073/pnas.0507535103

26. Fierer, N., Bradford, M. A. and Jackson, R. B. (2007). Toward an ecological classification of soil bacteria. Ecology, 88, 1354-1364. https://doi.org/10.1890/05-1839

27. Ford, H., Roberts, A. and Jones, L. (2016). Nitrogen and phosphorus co-limitation and grazing moderate nitrogen impacts on plant growth and nutrient cycling in sand dune grassland. Science of The Total Environment, 542, 203-209. https://doi.org/10.1016/j.scitotenv.2015.10.089

28. Fraser, T. D., Lynch, D. H., ElizabethBent, Entz, M. H. and Dunfield, K. E. (2015). Soil bacterial phoD gene abundance and expression in response to applied phosphorus and long-term managemen. Soil Biology and Biochemistry, 88, 137-147. https://doi.org/10.1016/j.soilbio.2015.04.014

29. Fu, D., Wu, X., Duan, C., Chadwick, D. R. and Jones, D. L. (2020). Response of soil phosphorus fractions and fluxes to different vegetation restoration types in a subtropical mountain ecosystem. CATENA, 193, 104663. https://doi.org/10.1016/j.catena.2020.104663

30. Ge, S., Peng, L., Ren, Y. and Jiang, Y. (2014). Effect of straw and biochar on soil bulk density, cation exchange capacity and nitrogen absorption in apple orchard soil. Scitntia Agricultura Sinica, 47, 366373. https://doi.org/10.3864/j.issn.0578-1752.2014.02.016 
31. Geisseler, D. and Scow, K. M. (2014). Long-term effects of mineral fertilizers on soil microorganisms - A review. Soil Biology and Biochemistry, 75, 54-63. https://doi.org/10.1016/j.soilbio.2014.03.023

32. Gichangi, E. M., Mnkeni, P. N. S. and Brookes, P. C. (2009). Effects of goat manure and inorganic phosphate addition on soil inorganic and microbial biomass phosphorus fractions under laboratory incubation conditions. Soil Science and Plant Nutrition, 55, 764-771. https://doi.org/10.1111/j.17470765.2009.00415.x

33. Goldfarb, K. C., Karaoz, U., Hanson, C. A., Santee, C. A., Bradford, M. A., Treseder, K. K., Wallenstein, M. D. and Brodie, E. L. (2011). Differential growth responses of soil bacterial taxa to carbon substrates of varying chemical recalcitrance. Frontiers in Microbiology, 2, 94. https://doi.org/10.3389/fmicb.2011.00094

34. Hamamura, N., Olson, S. H., Ward, D. M. and Inskeep, W. P. (2006). Microbial population dynamics associated with crude-oil biodegradation in diverse soils. Applied and Environmental Microbiology, 72, 6316-6324. https://doi.org/10.1128/AEM.01015-06

35. Hayat, R., Ali, S., Amara, U., Khalid, R. and Ahmed, I. (2010). Soil beneficial bacteria and their role in plant growth promotion: a review. Ann Microbiol, 60, 579-598. https://doi.org/10.1007/s13213-0100117-1

36. Hedley, M. J., Stewart, J. W. B. and Chauhan, B. S. C. (1982). Changes in inorganic and organic soil phosphorus fractions induced by cultivation practices and by laboratory incubations. Soil Science Society of America Journal, 46, 970-976.

https://doi.org/10.2136/sssaj1982.03615995004600050017x

37. Helfenstein, J., Jegminat, J., McLaren, T. I. and Frossard, E. (2018). Soil solution phosphorus turnover: derivation, interpretation, and insights from a global compilation of isotope exchange kinetic studies. Biogeosciences, 15, 105-114. https://doi.org/10.5194/bg-15-105-2018

38. Helfenstein, J., Pistocchi, C., Oberson, A., Tamburini, F., Goll, D. S. and Frossard, E. (2020). Estimates of mean residence times of phosphorus in commonly considered inorganic soil phosphorus pools. Biogeosciences, 17, 441-454. https://doi.org/10.5194/bg-17-441-2020

39. Hou, E., Lu, X., Jiang, L., Wen, D. and Luo, Y. (2019). Quantifying soil phosphorus dynamics: a data assimilation approach. JGR Biogeosciences, 124, 2159-2173. https://doi.org/10.1029/2018JG004903

40. Katsalirou, E., Deng, S., Gerakis, A. and Nofziger, D. L. (2016). Long-term management effects on soil P, microbial biomass P, and phosphatase activities in prairie soils. European Journal of Soil Biology, 76, 61-69. https://doi.org/10.1016/j.ejsobi.2016.07.001

41. Koerselman, W. and Meuleman, A. F. M. (1996). The vegetation N:P Ratio: a new tool to detect the nature of nutrient limitation. Journal of Applied Ecology, 33, 1441-1450. https://doi.org/10.2307/2404783

42. Langenheder, S. and Prosser, J. I. (2008). Resource availability influences the diversity of a functional group of heterotrophic soil bacteria. Environmental Microbiology, 10, 2245-1256. 10.1111/j.14622920.2008.01647.xhttps://doi.org/ 
43. Li, X. (2001). Effects of grazing on phosphorus stock and forms in chestnut soil. ACTA Prataculturae sinica, 10, 28-32.

44. Liao, D., Zhang, C., Li, H., Lambers, H. and Zhang, F. (2020). Changes in soil phosphorus fractions following sole cropped and intercroppedmaize and faba bean grown on calcareous soil. Plant and Soil, 448, 587-601. https://doi.org/10.1007/s11104-020-04460-0

45. Lin, W., Huang, T., Leong, S. J. and Chiou, T. J. (2014). Long-distance call from phosphate: systemic regulation of phosphate starvation responses. Journal of Experimental Botany, 65, 1817-1827. https://doi.org/10.1093/jxb/ert431

46. Lindsay, E. A. and Cunningham, S. A. (2009). Livestock grazing exclusion and microhabitat variation affect invertebrates and litter decomposition rates in woodland remnants. Forest Ecology and Management, 285. https://doi.org/10.1016/j.foreco.2009.04.005

47. Liu, C., Wang, Y., Pan, K., Jin, Y., Lia, W. and Zhang, L. (2015). Effects of phosphorus application on photosynthetic carbon and nitrogen metabolism, water use efficiency and growth of dwarf bamboo (Fargesia rufa) subjected to water deficit. Plant Physiology and Biochemistry, 96, 20-28. https://doi.org/10.1016/j.plaphy.2015.07.018

48. Liu, J., Aronsson, H., Ulén, B. and Bergström, L. (2012). Potential phosphorus leaching from sandy topsoils with different fertilizer histories before and after application of pig slurry. Soil Use and Management, 28, 457-467. https://doi.org/10.1111/j.1475-2743.2012.00442.x

49. Liu, J., Li, C., Xing, Y., Wang, Y., Xue, Y., Wang, C. and Dang, T. (2020). Effects of long-term fertilization on soil organic phosphorus fractions and wheat yield in

50. farmland of Loess Plateau. Chinese Journal of Applied Ecology, 31, 157-164. https://doi.org/10.13287/j.1001-9332.202001.028

51. Liu, X., Bia, Q., Qiu, L., Li, K., Yang, X. and Lin, X. (2019). Increased risk of phosphorus and metal leaching from paddy soils after excessive manure application: Insights from a mesocosm study. Science of The Total Environment, 666, 778-785. https://doi.org/10.1016/j.scitotenv.2019.02.072

52. Liu, X., Chen, X., Tian, H., Liu, L. and Han, H. (2019). Effects of thinning and litter manipulation on soil phosphorus dynamicsin a Larixprincipis-rupprechtii plantation. Acta Ecologica Sinica, 39, 7686-7696. https://doi.org/10.5846 /stxb201809061907

53. Lohse, M., Bolger, A. M., Nagel, A., Fernie, A. R., Lunn, J. E., Stitt, M. and Usadel, B. (2012). RobiNA: a user-friendly, integrated software solution for RNA-Seq-based transcriptomics. Nucleic Acids Research, 40, W622-W627. https://doi.org/10.1093/nar/gks540

54. Luo, G., Ling, N., Nannipieri, P., Chen, H., Raza, W., Wang, M., Guo, S. and Shen, Q. (2017). Long-term fertilisation regimes affect the composition of the alkaline phosphomonoesterase encoding microbial community of a vertisol and its derivative soil fractions. Biol Fertil Soils, 53, 375-388. https://doi.org/10.1007/s00374-017-1183-3

55. Luo, Y., Wu, L., Shao, D. and Yan, Z. (1997). Effect of long-term management of pure Phyllostachys Pubescens stands on soil fertility. Forest Research, 10, 125-129.

https://doi.org/10.13275/j.cnki.lykxyj.1997.02.003 
56. Magoč, T., Salzberg, S. L. and Notes, A. (2011). FLASH: fast length adjustment of short reads to improve genome assemblies. Bioinformatics, 27, 2957-2963.

https://doi.org/10.1093/bioinformatics/btr507

57. Manthey, M. and Peper, J. (2010). Estimation of grazing intensity along grazing gradients - the bias of nonlinearity. Journal of Arid Environments, 74, 1351-1354.

https://doi.org/10.1016/j.jaridenv.2010.05.007

58. Maranguit, D., Guillaume, T. and Kuzyakov, Y. (2017). Land-use change affects phosphorus fractions in highly weathered tropical soils. CATENA, 149, 385-393.

https://doi.org/10.1016/j.catena.2016.10.010

59. Marcos, M. S., Bertiller, M. B. and Olivera, N. L. (2019). Microbial community composition and network analyses in arid soils of the Patagonian Monte under grazing disturbance reveal an important response of the community to soil particle size. Applied Soil Ecology, 138, 223-232. https://doi.org/10.1016/j.apsoil.2019.03.001

60. Martínez, L. J. and Zinck, J. A. (2004). Temporal variation of soil compaction and deterioration of soil quality in pasture areas of Colombian Amazonia. Soil and Tillage Research, 75, 3-18. https://doi.org/10.1016/j.still.2002.12.001

61. McGroddy, M. E., Silver, W. L., Jr. de Oliveira, R. C., de Mello, W. Z. and Keller, M. (2008). Retention of phosphorus in highly weathered soils under a lowland Amazonian forest ecosystem. Journal of Geophysical Research Biogeoences, 113, 608-615. https://doi.org/10.1029/2008JG000756

62. Murphy, J. and Riley, J. P. (1962). A modified single solution method for the determination of phosphate in natural waters. Analytica Chimica Acta, 27, 31-36. https://doi.org/10.1016/S00032670(00)88444-5

63. Nahas, E. (1996). Factors determining rock phosphate solubilization by microorganisms isolated from soil. World Journal of Microbiology and Biotechnology, 12, 567-572. https://doi.org/10.1007/BF00327716

64. Nannipieri, P., Giagnoni, L., Landi, L. and Renella, G. (2010) Role of Phosphatase Enzymes in Soil. In Bünemann, E. K. (Ed.), Phosphorus in Action, Soil Biology. pp. 215-243. Berlin Heidelberg: SpringerVerlag.

65. Nannipieri, P., Giagnoni, L., Renella, G., Puglisi, E., Ceccanti, B., Masciandaro, G., Fornasier, F., Moscatelli, M. C. and Marinari, S. (2012). Soil enzymology: classical and molecular approaches. Biology and Fertility of Soils, 48, 743-762. https://doi.org/10.1007/s00374-012-0723-0

66. Neufeldt, H., Silva, J. E. D., Ayarza, M. A. and Zech, W. (2000). Land-use effects on phosphorus fractions in Cerrado oxisols. Biology and Fertility of Soils, 31, 30-37. https://doi.org/10.1007/s003740050620

67. Pagliari, P. H. and Laboski, C. A. M. (2012). Investigation of the inorganic and organic phosphorus forms in animal manure. Journal of Environmental Quality, 41, 901-970. https://doi.org/10.2134/jeq2011.0451| 
68. Pereira, J., Barneze, A. S., Misselbrook, T. H., Coutinho, J., Moreira, N. and Trindade, H. (2013). Effects of a urease inhibitor and aluminium chloride alone or combined with a nitrification

69. inhibitor on gaseous $\mathrm{N}$ emissions following soil application of cattle urine. Biosystems Engineering, 115, 396-407. https://doi.org/10.1016/j.biosystemseng.2013.05.002

70. Phimmachanh, S., Ying, Z. and Beckline, M. (2015). Bamboo resources utilization: A potential source of income to support rural livelihoods. Applied Ecology and Environmental Sciences, 3, 176-183. https://doi.org/10.12691/aees-3-6-3

71. Pistocchia, C., Mészáros, É., Tamburini, F., Frossard, E. and Bünemann, E. K. (2018). Biological processes dominate phosphorus dynamics under low phosphorus availability in organic horizons of temperate forest soils. Soil Biology and Biochemistry, 126, 64-75.

https://doi.org/10.1016/j.soilbio.2018.08.013

72. Ragot, S. A., Huguenin-Elie, O., Kertesz, M. A., Frossard, E. and Bünemann, E. K. (2016). Total and active microbial communities and $p h o D$ as affected by phosphate depletion and $\mathrm{pH}$ in soil. Plant and Soil, 408, 15-30. https://doi.org/10.1007/s11104-016-2902-5

73. Richardson, A. E. and Simpson, R. J. (2011). Soil Microorganisms Mediating Phosphorus Availability Update on Microbial Phosphorus. Plant Physiology, 156, 989. https://doi.org/10.1104/pp.111.175448

74. Sardans, J., Peñuelas, J. and Estiarte, M. (2006). Warming and drought alter soil phosphatase activity and soil $\mathrm{P}$ availability in a Mediterranean shrubland. Plant and Soil, 289, 227-238. https://doi.org/10.1007/s11104-006-9131-2

75. Schachtman, D. P., Reid, R. J. and Ayling, S. M. (1998). Phosphorus uptake by plants: from soil to cell. Plant Physiology, 116, 447-453. https://doi.org/10.1104/pp.116.2.447

76. Shah, A. N., Tanveer, M., Shahzad, B., Yang, G., Fahad, S., Ali, S., Bukhari, M. A., Tung, S. A., Hafeez, A. and Souliyanonh, B. (2017). Soil compaction effects on soil health and cropproductivity: an overview. Environmental Science and Pollution Research, 24, 10056-10067. https://doi.org/10.1007/s11356-017-8421-y

77. Sigua, G. C., Jr. Chase, C. C. and Albano, J. (2014). Soil-extractable phosphorus and phosphorus saturation threshold in beef cattle pastures as affected by grazing management and forage type. Environmental Science and Pollution Research, 21, 1691-1700. https://doi.org/10.1007/s11356-0132050-x

78. Soltani, A., Khavazi, K., Asadi-Rahmani, H., Omidvari, M., Dahaji, P. A. and Mirhoseyni, H. (2010). Plant growth promoting characteristics in some Flavobacterium spp. isolated from soils of Iran. Journal of Agricultural Science, 2, 106-115. https://doi.org/10.5539/jas.v2n4p106 · Source: DOAJ

79. Somda, Z. C., Powell, J. M. and Bationo, A. (1997). Soil pH and nitrogen changes following cattle and sheep urine deposition. Communications in Soil Science and Plant Analysis, 28, 1253-1268. https://doi.org/10.1080/00103629709369872

80. Song, X., Zhou, G., Jiang, H., Yu, S., Fu, J., Li, W., Wang, W., Ma, Z. and Peng, C. (2011). Carbon sequestration by Chinese bamboo forests and their ecological benefits: assessment of potential, 
problems, and future challenges. Environmental Reviews, 19, 418-428. https://doi.org/10.1139/a11015

81. Spohn, M. and Schleuss, P. (2019). Addition of inorganic phosphorus to soil leads to desorption of organic compounds and thus to increased soil respiration. Soil Biology and Biochemistry, 130, $220-$ 226. https://doi.org/10.1016/j.soilbio.2018.12.018

82. Stopnisek, N., Bodenhausen, N., Frey, B., Fierer, N., Eberl, L. and Weisskopf, L. (2014). Genus-wide acid tolerance accounts for the biogeographical distribution of soil Burkholderia populations. Environmental Microbiology, 16, 1503-1512. https://doi.org/10.1111/1462-2920.12211

83. Stumpp, M., Wesche, K., Retzer, V. and Miehe, G. (2005). Impact of grazing livestock and distance from water source on soil fertility in Southern Mongolia. Mountain Research and Development, 25, 244-251. https://doi.org/10.1659/0276-4741(2005)025[0244:IOGLAD]2.0.C0;2

84. Stutter, M. and Richards, S. (2018). A novel approach to evaluating relationships between soil test and runoff $\mathrm{P}$ at landscape scales by integrating farmer knowledge on soil drains. Agriculture, Ecosystems \& Environment, 254, 179-190. https://doi.org/10.1016/j.agee.2017.11.026

85. Sugiyama, S., Kitora, R., Kinoshita, H., Nakagawa, K., Katoh, M. and Nakasaki, K. (2016). Recovery of calcium phosphates from composted chicken manure. Journal of chemical engineering of Japan, 49, 224-228. https://doi.org/10.1252/jcej.15we111

86. Tabatabai, M. A. and Bremner, J. M. (1969). Use of p-nitrophenyl phosphate for assay of soil phosphatase activity. Soil Biology and Biochemistry, 1, 301-307. https://doi.org/10.1016/00380717(69)90012-1

87. Tan, H., Barret, M., Mooij, M. J., Rice, O., Morrissey, J. P., Dobson, A., Griffiths, B. and Gara, F. O. (2013). Long-term phosphorus fertilisation increased the diversity of the total bacterial community and the phoD phosphorus mineraliser group in pasture soils. Biology and Fertility of Soils, 49, 661-672. https://doi.org/10.1007/s00374-012-0755-5

88. Tarafdar, J. C. and Claassen, N. (1988). Organic phosphorus compounds as a phosphorus source for higher plants through the activity of phosphatases produced by plant roots and microorganisms. Biology and Fertility of Soils, 5, 308-312. https://doi.org/10.1007/BF00262137

89. Tarafdar, J. C. and Jungk, A. (1987). Phosphatase activity in the rhizosphere and its relation to the depletion of soil organic phosphorus. Biology and Fertility of Soils, 3, 199-204. https://doi.org/10.1007/BF00640630

90. Teague, W. R., Dowhower, S. L., Baker, S. A., Haile, N., DeLaune, P. B. and Conover, D. M. (2011). Grazing management impacts on vegetation, soil biota and soil chemical, physical and hydrological properties in tall grass prairie. Agriculture, Ecosystems \& Environment, 141, 310-322. https://doi.org/10.1016/j.agee.2011.03.009

91. Thomas, F., Hehemann, J., Rebuffet, E., Czjzek, M. and Michel, G. (2011). Environmental and gut Bacteroidetes: the food connection. Frontiers in Microbiology, 2, 93. https://doi.org/10.3389/fmicb.2011.00093 
92. Tian, J., Lu, X., Chen, Q., Kuang, X., Liang, C., Deng, L., Lin, D., Cai, K. and Tian, J. (2020). Phosphorus fertilization affects soybean rhizosphere phosphorus dynamics and the bacterial community in karst soils. Plant and Soil. https://doi.org/10.1007/s11104-020-04662-6

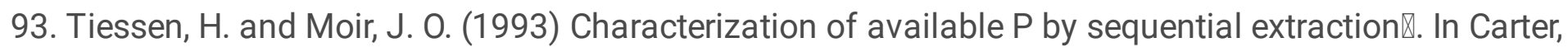
M. R. (Ed.), Soil Sampling and Methods of Analysis. pp. 293-306. Boca Raton: CRC Press LLC.

94. Tipping, E., Somerville, C. J. and Luster, J. (2016). The C:N:P:S stoichiometry of soil organic matter. Biogeochemistry, 130, 117-137. https://doi.org/10.1007/s10533-016-0247-z

95. Tokural, A. M., Netoll, A. E. F., Carneirolll, L. F., Curill, N., Santosll, J. Z. L. and AlovisilV, A. A. (2011). Dynamics of phosphorus forms in soils with contrasting texture and mineralogy cultivated with rice. Acta Scientiarum. Agronomy, 33, 171-179. https://doi.org/10.4025/actasciagron.v33i1.1435

96. Verbon, E. H. and Liberman, L. M. (2016). Beneficial microbes affect endogenous mechanisms controlling root development. Trends in Plant Science, 21, 218-229.

https://doi.org/10.1016/j.tplants.2016.01.013

97. Vitousek, P. M., Porder, S., Houlton, B. Z. and Chadwick, O. A. (2010a). Terrestrial phosphorus limitation: mechanisms, implications, and nitrogen-phosphorus interactions. Ecological Applications, 20, 5-15. https://doi.org/10.1890/08-0127.1

98. Wang, J., Song, Y., Ma, T., Raza, W., Li, J., Howland, J. G., Huang, Q. and Shena, Q. (2017). Impacts of inorganic and organic fertilization treatments on bacterial and fungal communities in a paddy soil. Applied Soil Ecology, 112, 42-50. https://doi.org/10.1016/j.apsoil.2017.01.005

99. Wang, Q., Wang, C., Yu, W., Turak, A., Chen, D., Huang, Y., Ao, J., Jiang, Y. and Huang, Z. (2018). Effects of Nitrogen and Phosphorus Inputs on Soil Bacterial Abundance, Diversity, and Community Composition in Chinese Fir Plantations. Frontiers in Microbiology, 9, 1543. https://doi.org/10.3389/fmicb.2018.01543

100. Wang, Y., Ji, H. and Gao, C. (2016). Differential responses of soil bacterial taxa to long-term $P, N$, and organic manure application. Journal of Soils and Sediments, 16, 1046-1058. https://doi.org/10.1007/s11368-015-1320-2

101. Waring, B. G., Weintraub, S. R. and Sinsabaugh, R. L. (2014). Ecoenzymatic stoichiometry of microbial nutrient acquisition in tropical soils. Biogeochemistry, 117, 101-113. https://doi.org/10.1007/s10533-013-9849-x

102. Williams, P. H. and Haynes, R. J. (1990). Influence of improved pastures and grazing animals on nutrient cycling within new Zealand soils. New Zealand Journal of Ecology, 14, 49-57.

103. Wu, X., Miao, J., Zheng, Y., Pan, F., Liu, T., Yi, L., Xia, G. and Wen, G. (2013). Forest floor fed chickens and biodiversity. Journal of Zhejiang A $\square$ F University, 30, 689-697. https://doi.org/10.11833/j.issn.2095-0756.2013.05.009

104. Yan, Y., Wang, X., Liu, F. and Feng, X. (2019). Progress in researches on interactions between organic phosphates and soil minerals and their environmental impacts. Acta Pedologica Sinica, 56, 12901299. https://doi.org/10.11766/trxb201811100553 
105. Yan, Z., Chen, S., Wang, M., Song, Z. and Chen, Q. (2015). Characteristics and availability of different forms of phosphorus in animal manures. Journal of Agricultural Resources and Enbironment, 32, 3139. https://doi.org/10.13254/j.jare.2014.0283

106. Yang, Z., Baoyin, T., Minggagud, H., Sun, H. and Li, F. Y. (2017). Recovery succession drives the convergence, and grazing versus fencing drives the divergence of plant and soil N/P stoichiometry in a semiarid steppe of Inner Mongolia. Plant and Soil, 420, 303-314. https://doi.org/10.1007/s11104017-3404-9

107. Zhan, T., Zhang, Z., Sun, J., Liu, M., Zhang, X., Peng, F., Tsunekawa, A., Zhou, H., Gou, X. and Fu, S. (2020). Meta-analysis demonstrating that moderate grazing can improve the soil quality across China's grassland ecosystems. Applied Soil Ecology, 147, 103438. https://doi.org/10.1016/j.apsoil.2019.103438

108. Zhang, H., Shi, L., Lu, H., Shao, Y., Liu, S. and Fu, S. (2020). Drought promotes soil phosphorus transformation and reduces phosphorus bioavailability in a temperate forest. Science of The Total Environment, 732, 139295. https://doi.org/10.1016/j.scitotenv.2020.139295

109. Zhang, J. (1990). Microorganism classification. Shanhai: Fudan University Press.

110. Zhang, X., Gai, X., Yang, C., Ying, J., Li, W., Du, X., Zhong, Z., Shao, Q. and Bian, F. (2020). Effects of chicken farming on soil properties and root-associated bacterial communities in a bamboo (Phyllostachys praecox) ecosystem. Applied Soil Ecology, 157, 103725. https://doi.org/10.1016/j.apsoil.2020.103725

111. Zhang, X., Gao, G., Wu, Z., Wen, X., Zhong, H., Zhong, Z., Bian, F. and Gai, X. (2019). Agroforestry alters the rhizosphere soil bacterial and fungal communities of moso bamboo plantations in subtropical China. Applied Soil Ecology, 143, 192-200. https://doi.org/10.1016/j.apsoil.2019.07.019

112. Zhang, X., Zhong, Z., Gai, X., Ying, J., Li, W., Du, X., Bian, F. and Yang, C. (2019). Leaf-Associated Shifts in Bacterial and Fungal Communities in Response to Chicken Rearing Under Moso Bamboo Forests in Subtropical China. Forests, 10, 216. https://doi.org/10.3390/f10030216

113. Zhang, Y., Gao, X., Hao, X., Alexander, T. W., Shi, X., Jin, L. and Thomasd, B. W. (2020). Heavy grazing over 64 years reduced soil bacterial diversity in the foothills of the Rocky Mountains, Canada. Applied Soil Ecology, 147, 103361. https://doi.org/10.1016/j.apsoil.2019.09.011

114. Zhao, J., Wang, F., Lia, J., Zou, B., Wang, X., Li, Z. and Fu, S. (2014). Effects of experimental nitrogen and/or phosphorus additions on soil nematode communities in a secondary tropical forest. Soil Biology and Biochemistry, 75, 1-10. https://doi.org/10.1016/j.soilbio.2014.03.019

115. Zhao, Y., Zhang, M., Yang, W., Di, H. J., Ma, L., Liu, W. and Li, B. (2019). Effects of microbial inoculants on phosphorus and potassium availability, bacterial community composition, and chili pepper growth in a calcareous soil: a greenhouse study. Journal of Soils and Sediments, 19, 3597-3607. https://doi.org/10.1007/s11368-019-02319-1

116. Zhu, C., Yang, C., Shen, X. and Wang, B. (2018). Effect of raising chicken on soil quality and bamboo growth in Phyllostachys edulis forest. Journal of Bamboo Research, 37, 49-53. https://doi.org/10.19560/j.cnki.issn1000-6567.2018.01.008 
117. Zhu, Y. (2012). Study on economic efficiency of forest-chicken compound management patterns in the lower Yellow River. Chinese Agricultural Science Bulletin, 28, 70-73.

\section{Figures}

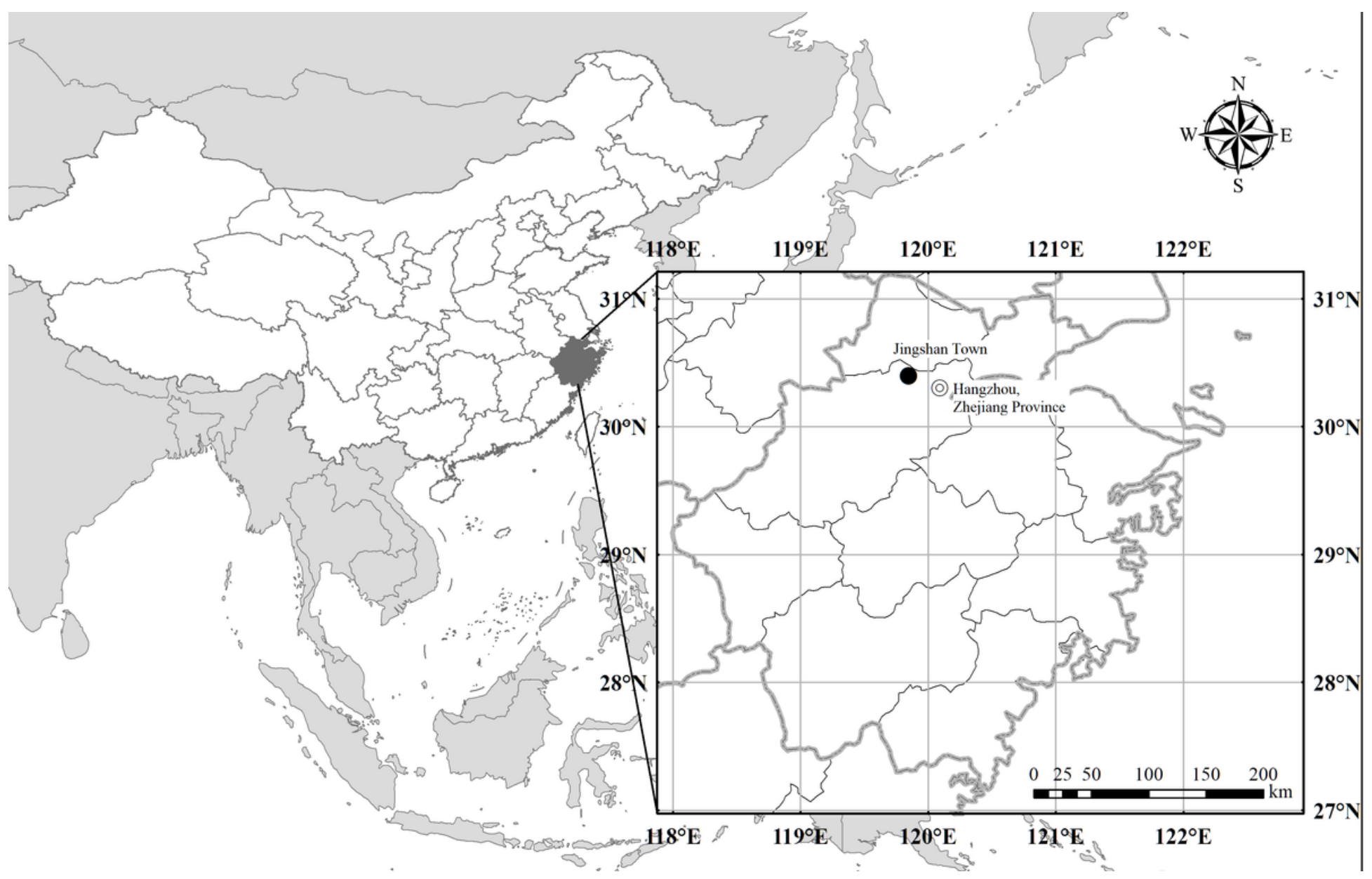

\section{Figure 1}

Location map of the experimental site: Jingshan Town, northwest of Hangzhou in Zhejiang Province, southeast China. Note: The designations employed and the presentation of the material on this map do not imply the expression of any opinion whatsoever on the part of Research Square concerning the legal status of any country, territory, city or area or of its authorities, or concerning the delimitation of its frontiers or boundaries. This map has been provided by the authors. 

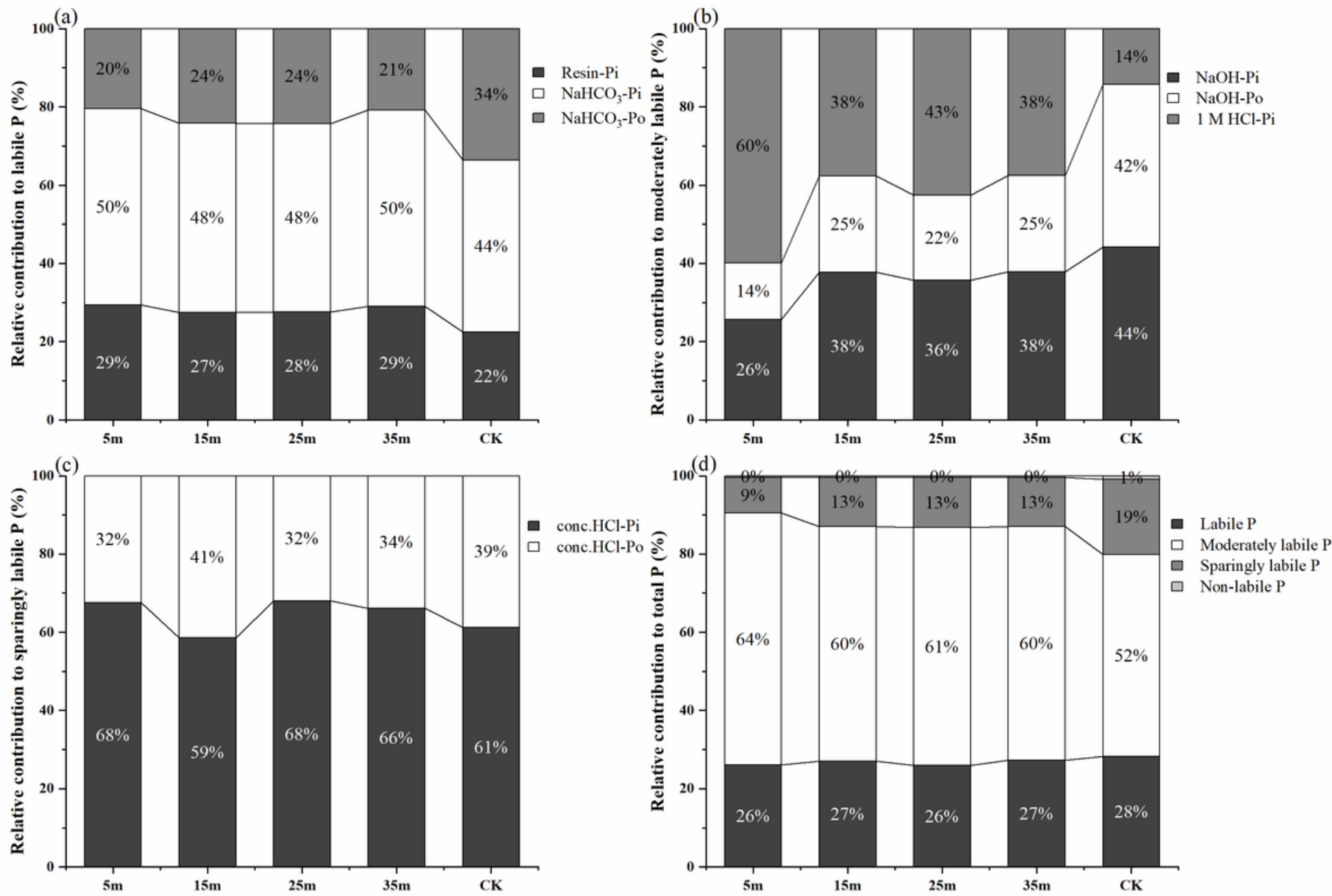

Figure 2

Percentage of each phosphorus $(P)$ fraction in labile $P(a)$, moderately labile $P(b)$, sparingly labile $P(c)$, and total $P(d)$ at the different grazing sites.
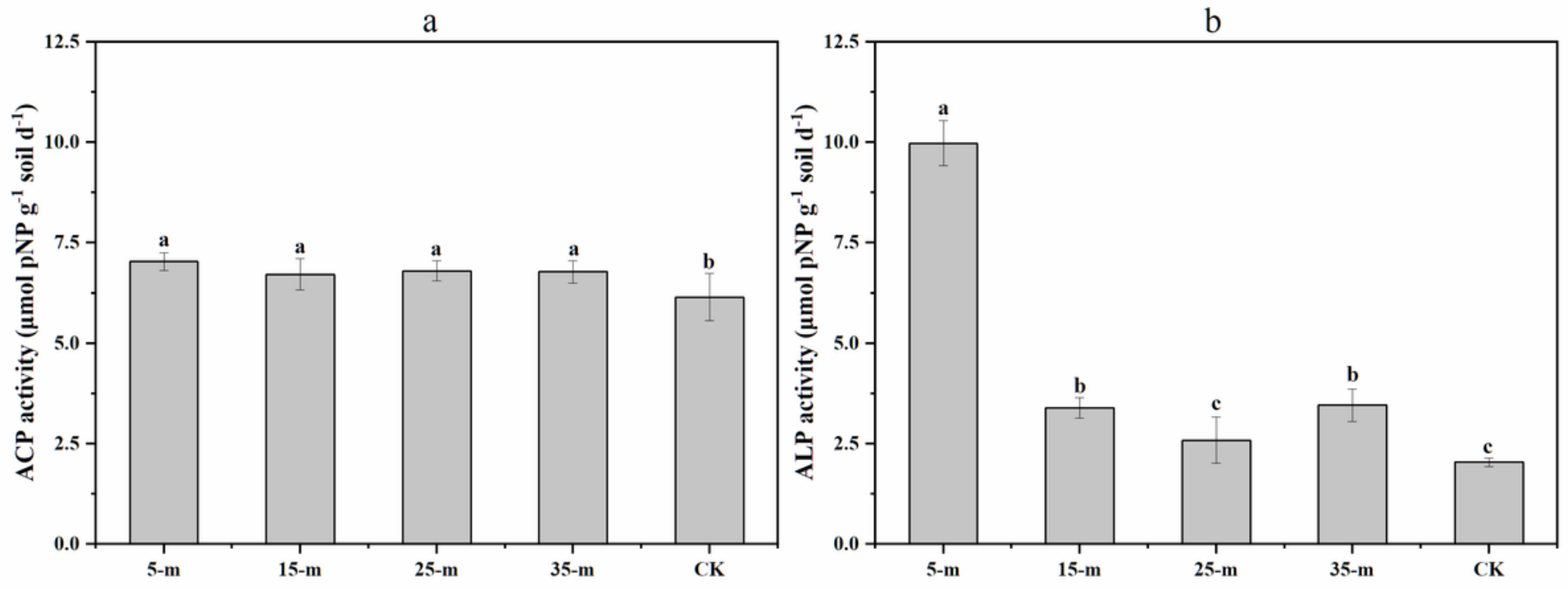

Figure 3 
Acid phosphatase (a) and alkaline phosphatase (b) activity in the bamboo forest soil under different grazing distances from the hen house. The error bars indicate the standard error of the mean $(n=5)$. According to Duncan's test, the different letters indicate significant differences at $p<0.05$.

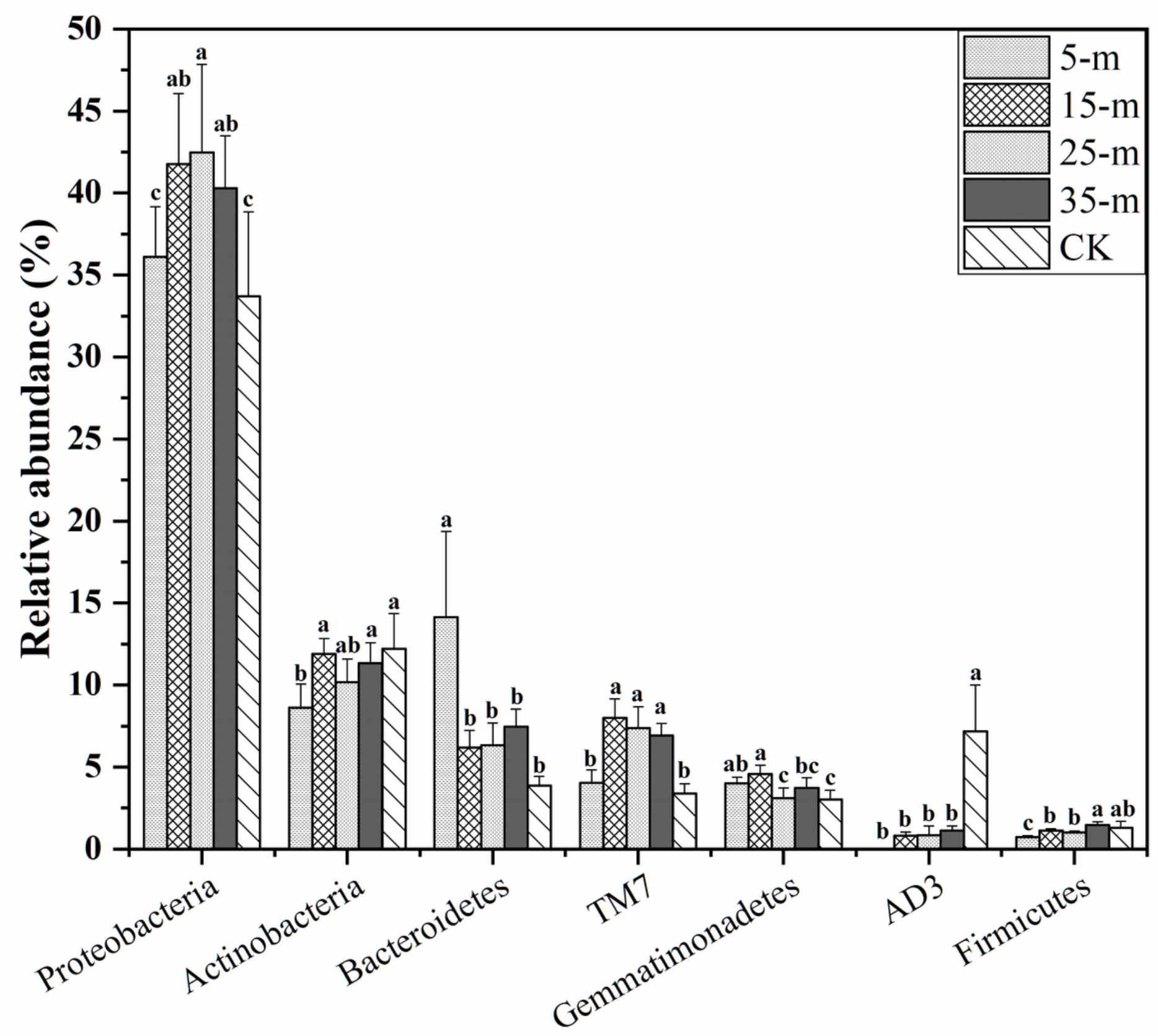

Figure 4

Differences in the dominant phyla (average relative abundance $>1 \%$ ) of soil bacteria at different distances from the hen house. 


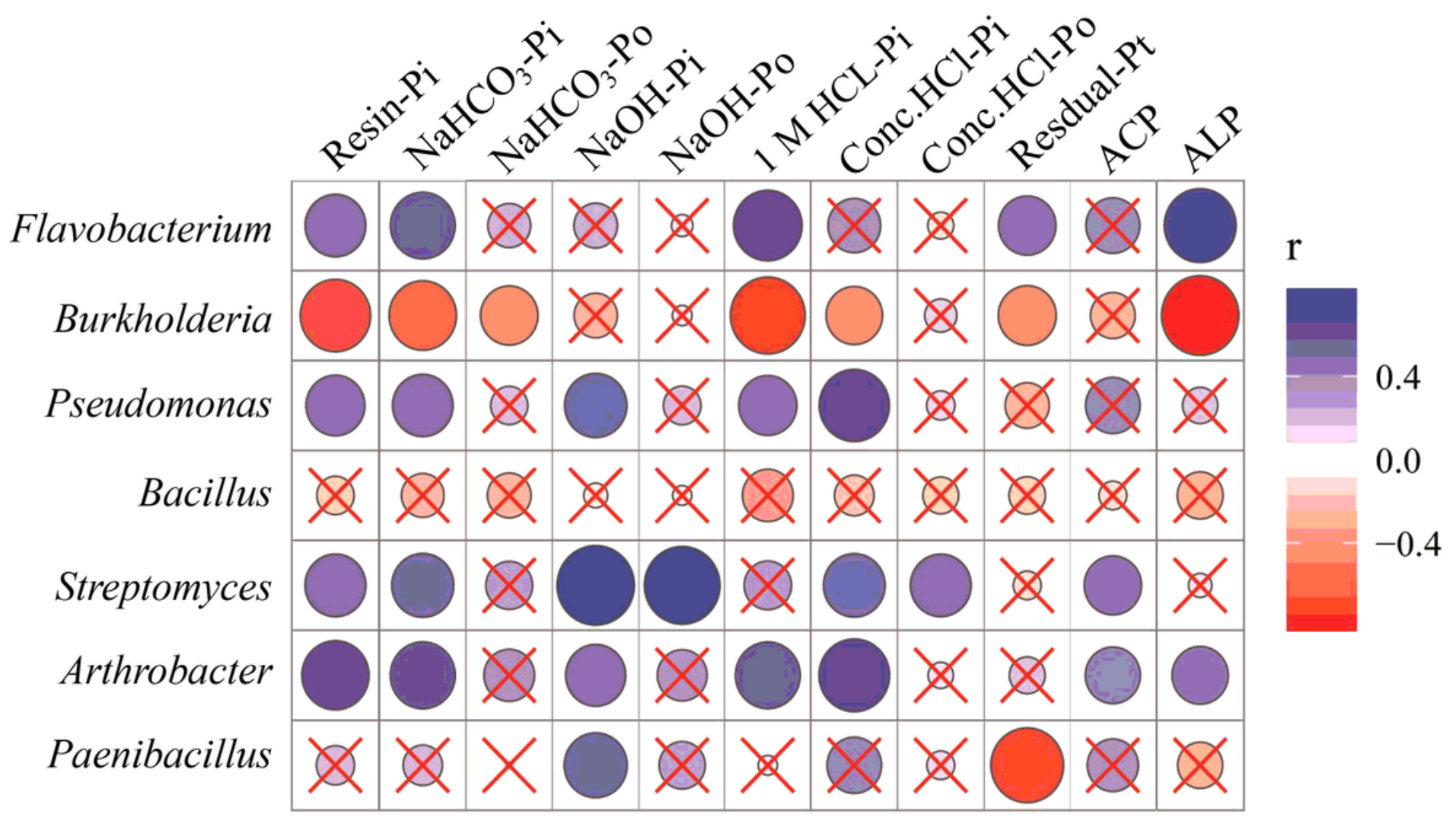

Figure 5

Pearson correlation analysis between soil phosphorus fractions and the phosphobacteria genera. 


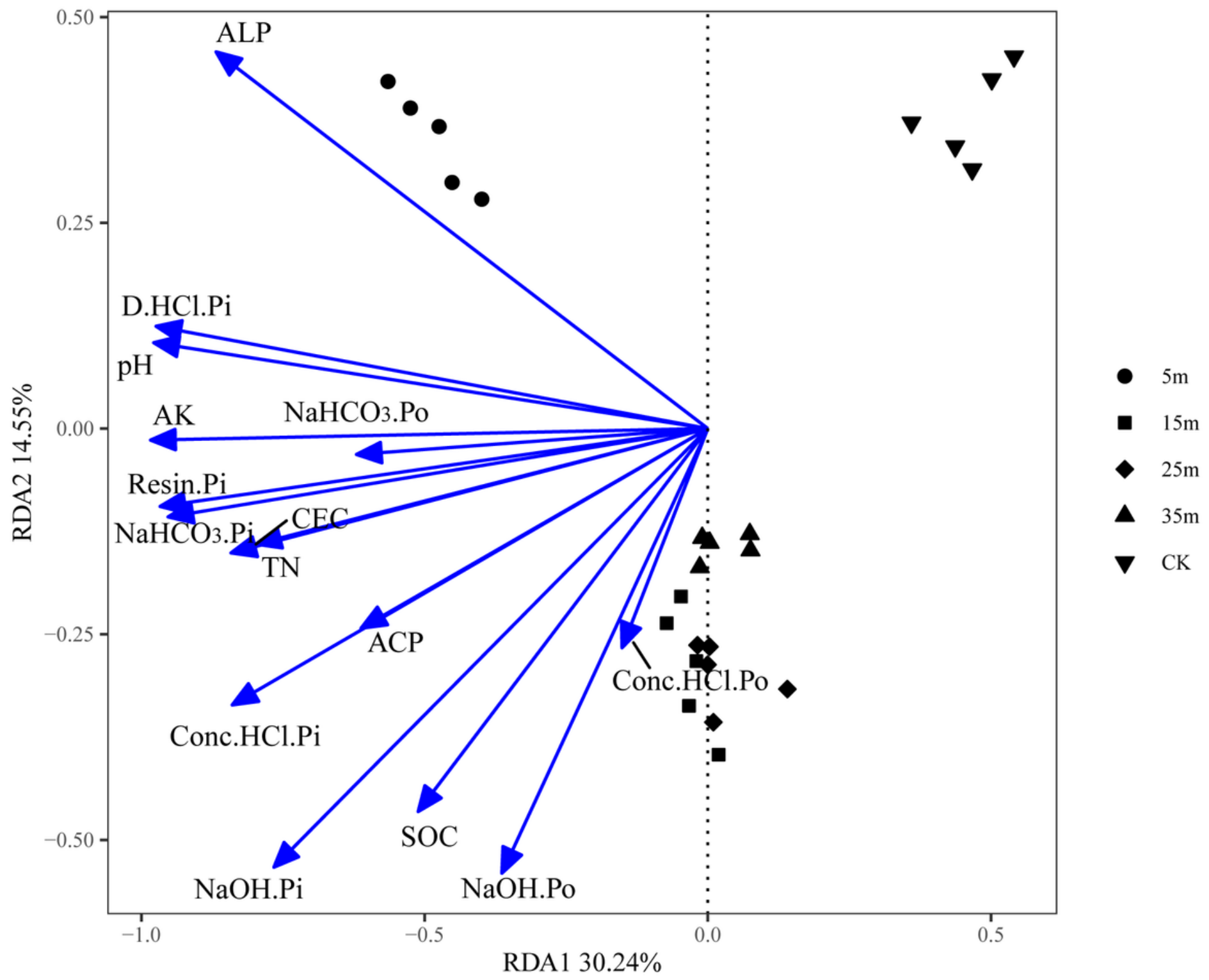

Figure 6

Redundancy analysis of the selected soil properties, phosphorus fractions, and phosphatase for bacterial community structures.

\section{Supplementary Files}

This is a list of supplementary files associated with this preprint. Click to download.

- Supplementarymaterial.docx 